\title{
Palladium(II) complexes of a neutral CCC-tris(N-heterocyclic carbene) pincer ligand: Synthesis and catalytic applications
}

David Rendon-Nava ${ }^{a}$, Deyanira Angeles-Beltrán ${ }^{\mathrm{b}}$, Arnold Rheingold ${ }^{\mathrm{c}}$, and Daniel MendozaEspinosa $^{\text {a* }}$

aÁrea Académica de Química, Universidad Autónoma del Estado de Hidalgo, Carretera PachucaTulancingo Km. 4.5, Mineral de la Reforma, Hidalgo, México.

${ }^{\mathrm{b}}$ Departamento de Ciencias Básicas, Universidad Autónoma Metropolitana-Azcapotzalco, Avenida San Pablo 180, Ciudad de México, Mexico, 02200.

$\mathrm{c}^{\mathrm{c}}$ Department of Chemistry and Biochemistry, University of California, 9500 Gilman Drive, La Jolla, San Diego, California 92093, USA.

Supporting information

\section{Contents:}

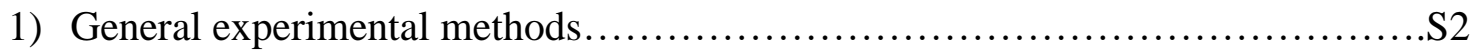

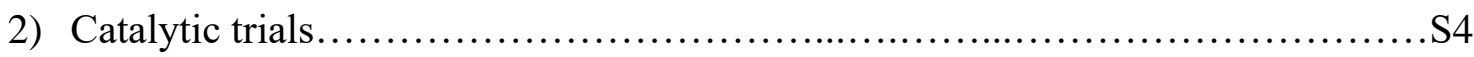

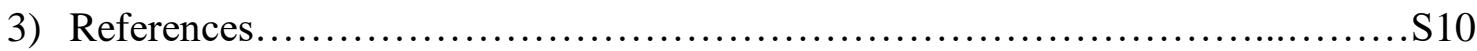

5) Sample ${ }^{1} \mathrm{H}$ and ${ }^{13} \mathrm{C}$ NMR spectra for new products............................. 12 


\section{Experimental section}

\section{General methods}

Commercially available reagents and solvents were used as received. 1,3-Dipropargylimidazolium bromide $^{1}$ and mesityl azide ${ }^{2}$ were synthesized as reported in the literature. Synthesis of all metal complexes was performed under nitrogen atmosphere using standard Schlenk techniques. Solvents were dried by standard methods and distilled under nitrogen. Melting points were determined on a Fisher-Johns apparatus and are uncorrected. NMR spectra were obtained with a Bruker Ascend (400 $\mathrm{MHz}$ ) spectrometer. Elemental analyses were obtained with a Thermo Finnegan CHNSO-1112 apparatus and a Perkin Elmer Series II CHNS/O 2400 instruments. GC-MS analyses were performed in an Agilent GC model HP 5890 coupled with a mass detector model 5973. X-Ray diffraction analyses were collected in an Agilent Gemini Diffractometer using Mo K $\alpha$ radiation $(1=0.71073 \AA$ ). Data were integrated, scaled, sorted, and averaged using the CrysAlisPro software package. The structures we solved using direct methods, using SHELX 2014 and refined by full matrix least squares against $\mathrm{F}^{2} \cdot{ }^{3}$ All non-hydrogen atoms were refined anisotropically.

\section{Catalytic trials}

General procedure for the Suzuki-Miyaura coupling of aryl chlorides and boronic acids.

Sodium tert-butoxide $(1.5 \mathrm{mmol})$ and boronic acid $(1.3 \mathrm{mmol})$ were charged in a $10 \mathrm{~mL}$ screw capped vial equipped with a magnetic bar. The catalyst ( $1 \mathrm{~mol} \%$ ) and $5 \mathrm{~mL}$ of anhydrous dioxane were added and the mixture was stirred for 15 minutes. The aryl chloride $(1 \mathrm{mmol})$ was added in one portion, and the reaction mixture was stirred at room temperature for 2 hours and monitored by ${ }^{1} \mathrm{H}$ NMR spectroscopy. Water was added to the reaction mixture, the organic layer was extracted with ethyl acetate, dried with magnesium sulfate, and the solvent was evaporated under vacuum. When necessary the product was purified by column chromatography on silica gel using a proper mixture of ethyl acetate/hexanes as eluent.

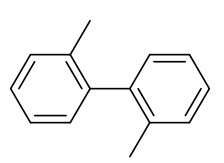

2,2-dimethyl-1,1'-biphenyl (Table 2, entry 1): The general procedure afforded the title compound in 97\% (179 mg, colorless liquid) isolated yield after column chromatography using a mixture of 5:95 ethyl acetate/hexane as eluent $\left(\mathrm{R}_{\mathrm{f}}=0.74\right)$.

${ }^{1} \mathrm{H}-\mathrm{NMR}\left(\mathrm{CDCl}_{3}, 400 \mathrm{MHz}\right): \delta=7.19-7.26(\mathrm{~m}, 6 \mathrm{H}, \mathrm{ArH}), 7.09(\mathrm{~d}, J=6.8 \mathrm{~Hz}, 2 \mathrm{H}, \mathrm{ArH}), 2.05(\mathrm{~s}, 6 \mathrm{H}$, $\left.\mathrm{CH}_{3}\right) ;{ }^{13} \mathrm{C}-\mathrm{NMR}\left(\mathrm{CDCl}_{3}, 100 \mathrm{MHz}\right) \delta=19.8,125.5,127.1,129.3,129.8,135.8,141.6$. Spectroscopy data is consistent with the literature. ${ }^{4}$ 


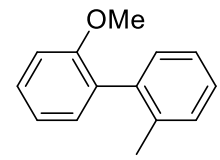

2-methoxy-2'-methyl-1,1'-biphenyl (Table 2, entry 2): The general procedure afforded the title compound in $94 \%$ (186 mg, colorless liquid) isolated yield after column chromatography using a mixture of 15:85 ethyl acetate/hexane as eluent $\left(\mathrm{R}_{\mathrm{f}}\right.$ $=0.55) .{ }^{1} \mathrm{H}-\mathrm{NMR}\left(\mathrm{CDCl}_{3}, 400 \mathrm{MHz}\right): \delta=7.30-7.32(\mathrm{~m}, 1 \mathrm{H}, \mathrm{ArH}), 7.14-7.23(\mathrm{~m}, 5 \mathrm{H}, \mathrm{ArH})$, 6.94$7.02(\mathrm{~m}, 2 \mathrm{H}, \mathrm{ArH}), 3.73\left(\mathrm{~s}, 3 \mathrm{H}, \mathrm{OCH}_{3}\right), 2.13\left(\mathrm{~s}, 3 \mathrm{H}, \mathrm{CH}_{3}\right) ;{ }^{13} \mathrm{C}-\mathrm{NMR}\left(\mathrm{CDCl}_{3}, 100 \mathrm{MHz}\right) \delta=19.9$, $55.4,110.7,120.5,125.5,127.3,128.6,129.6,130.0,130.9$ 131.0, 136.8, 138.7, 156.5. Spectroscopy data is consistent with the literature. ${ }^{4}$

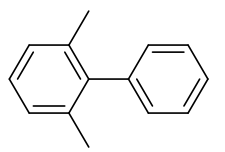

2,6-dimethyl-biphenyl (Table 2, entry 3): The general procedure afforded the title compound in 96\% (175 mg, colorless liquid) isolated yield after column chromatography using a mixture of 10:90 ethyl acetate/hexane as eluent $\left(R_{f}=0.68\right)$. ${ }^{1} \mathrm{H}-\mathrm{NMR}\left(\mathrm{CDCl}_{3}, 400 \mathrm{MHz}\right): \delta=7.39(\mathrm{t}, J=7.4 \mathrm{~Hz}, 2 \mathrm{H}, \mathrm{ArH}), 7.31(\mathrm{~d}, J=6.8 \mathrm{~Hz}, 1 \mathrm{H}, \mathrm{ArH}), 7.07-$ $7.13(\mathrm{~m}, 5 \mathrm{H}, \mathrm{ArH}), 2.01\left(\mathrm{~s}, 6 \mathrm{H}, \mathrm{CH}_{3}\right) ;{ }^{13} \mathrm{C}-\mathrm{NMR}\left(\mathrm{CDCl}_{3}, 100 \mathrm{MHz}\right) \delta=20.9,126.5,127.1,127.3$, $128.5,129.1,136.1,141.1,141.9$. Spectroscopy data is consistent with the literature. ${ }^{4}$

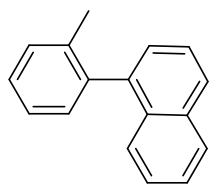

1-(o-tolyl)naphthalene (Table 2, entry 4): The general procedure afforded the title compound in $91 \%$ (199 mg, while solid) isolated yield after column chromatography using a mixture of 15:85 ethyl acetate/hexane as eluent $\left(\mathrm{R}_{\mathrm{f}}=0.38\right) .{ }^{1} \mathrm{H}-\mathrm{NMR}\left(\mathrm{CDCl}_{3}\right.$, $400 \mathrm{MHz}): \delta=7.89(\mathrm{~d}, J=8.0 \mathrm{~Hz}, 1 \mathrm{H}, \operatorname{Ar} H), 7.85(\mathrm{~d}, J=8.4 \mathrm{~Hz}, 1 \mathrm{H}, \mathrm{ArH}), 7.51(\mathrm{dt}$, $J=1.5,7.7 \mathrm{~Hz}, 1 \mathrm{H}, \mathrm{ArH}), 7.44-7.48(\mathrm{~m}, 2 \mathrm{H}, \mathrm{ArH}), 7.23-7.39(\mathrm{~m}, 6 \mathrm{H}, \mathrm{ArH}), 2.02\left(\mathrm{~s}, 3 \mathrm{H}, \mathrm{CH}_{3}\right) ;{ }^{13} \mathrm{C}-$ NMR $\left(\mathrm{CDCl}_{3}, 100 \mathrm{MHz}\right) \delta=20.0,125.4,125.6,125.7,125.9,126.1,126.6,127.4,127.5,128.2$, $129.8,130.4,132.0,133.5,136.8,139.8,140.2$. Spectroscopy data is consistent with the literature. ${ }^{5}$

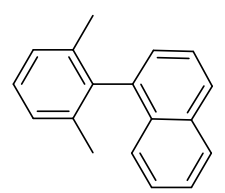

1-(2,6-dimtehylphenyl)naphthalene (Table 2, entry 5): The general procedure afforded the title compound in $90 \%$ (207 $\mathrm{mg}$, while solid) isolated yield after column chromatography using a mixture of 15:85 ethyl acetate/hexane as eluent $\left(R_{f}=0.44\right)$. ${ }^{1} \mathrm{H}-\mathrm{NMR}\left(\mathrm{CDCl}_{3}, 400 \mathrm{MHz}\right): \delta=7.91(\mathrm{~d}, J=7.8 \mathrm{~Hz}, 1 \mathrm{H}, \mathrm{ArH}), 7.87(\mathrm{~d}, J=8.2 \mathrm{~Hz}$, 1H, $\operatorname{Ar} H), 7.55(\mathrm{t}, J=7.8 \mathrm{~Hz}, 1 \mathrm{H}, \operatorname{Ar} H), 7.47$ (t, $J=6.9 \mathrm{~Hz}, 1 \mathrm{H}, \operatorname{Ar} H), 7.38-7.32(\mathrm{~m}, 2 \mathrm{H}, \operatorname{Ar} H), 7.30$ $7.22(\mathrm{~m}, 2 \mathrm{H}, \mathrm{ArH}), 7.20-7.15(\mathrm{~m}, 2 \mathrm{H}, \mathrm{ArH}), 1.92\left(\mathrm{~s}, 6 \mathrm{H}, \mathrm{CH}_{3}\right) ;{ }^{13} \mathrm{C}-\mathrm{NMR}\left(\mathrm{CDCl}_{3}, 100 \mathrm{MHz}\right) \delta=$ 20.4, 125.4, 125.6, 125.7, 126.0, 126.4, 127.1, 127.2, 127.3, 128.3, 131.7, 133.7, 137.0, 138.7, 139.6. Spectroscopy data is consistent with the literature. ${ }^{6}$

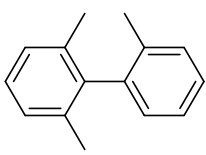

2,2',6-trimethyl-biphenyl (Table 2, entry 6): The general procedure afforded the title compound in $92 \%$ (181 mg, colorless liquid) isolated yield after column chromatography using a mixture of 5:95 ethyl acetate/hexane as eluent $\left(R_{\mathrm{f}}=0.62\right)$. 
${ }^{1} \mathrm{H}-\mathrm{NMR}\left(\mathrm{CDCl}_{3}, 400 \mathrm{MHz}\right): \delta=7.09-7.29(\mathrm{~m}, 6 \mathrm{H}, \mathrm{ArH}), 6.99-7.02(\mathrm{~m}, 1 \mathrm{H}, \mathrm{ArH}), 1.96\left(\mathrm{~s}, 3 \mathrm{H}, \mathrm{CH}_{3}\right)$, $1.92\left(\mathrm{~s}, 6 \mathrm{H}, \mathrm{CH}_{3}\right) ;{ }^{13} \mathrm{C}-\mathrm{NMR}\left(\mathrm{CDCl}_{3}, 100 \mathrm{MHz}\right) \delta=19.4$ 20.3, 126.0, 126.9, 127.0, 127.2, 128.8, $130.0,135.6,135.8140 .5,141.1$. Spectroscopy data is consistent with the literature. ${ }^{4}$

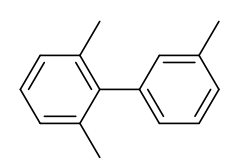

2,3',6-trimethyl-biphenyl (Table 2, entry 7): The general procedure afforded the title compound in 93\% (184 mg, colorless liquid) isolated yield after column chromatography using a mixture of 5:95 ethyl acetate/hexane as eluent $\left(R_{f}=0.64\right)$. ${ }^{1} \mathrm{H}-\mathrm{NMR}\left(\mathrm{CDCl}_{3}, 400 \mathrm{MHz}\right): \delta=7.13-7.17$ (m, 1H, $\left.\mathrm{ArH}\right), 6.96-7.01$ (m, 4H, ArH), 6.78-6.83 (m, $2 \mathrm{H}, \mathrm{ArH}), 2.22\left(\mathrm{~s}, 3 \mathrm{H}, \mathrm{CH}_{3}\right), 1.90\left(\mathrm{~s}, 6 \mathrm{H}, \mathrm{CH}_{3}\right) ;{ }^{13} \mathrm{C}-\mathrm{NMR}\left(\mathrm{CDCl}_{3}, 100 \mathrm{MHz}\right) \delta=20.9,21.6,126.1$, 127.0, 127.3, 127.4, 128.4, 129.8, 136.1, 138.0, 141.1, 142.1. Spectroscopy data is consistent with the literature. ${ }^{4}$

\section{General procedure for catalytic preparation of amides.}

A thick walled Schlenk tube was equipped with a magnetic stir bar, was loaded with $\mathrm{K}_{2} \mathrm{CO}_{3}(1.2$ equiv), the catalyst $(3 \mathrm{~mol} \%)$, the appropriate ester $(1.0 \mathrm{mmol})$, and aniline $(1.2 \mathrm{mmol})$. The Schlenk tube was placed under vacuum and purged with nitrogen for three times. Toluene $(3 \mathrm{~mL})$ and degassed water (20 equiv) were subsequently added to the reaction mixture and the contents were heated at 80 ${ }^{\circ} \mathrm{C}$ for $16 \mathrm{~h}$. After cooling to room temperature, the reaction mixture was diluted with ethyl acetate and the organic phase was washed with water and brine, and further dried with magnesium sulfate. The crude mixture was concentrated in vacuo and subjected to purification by column chromatography.

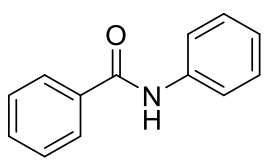

benzanilide (Table 3, entry 1) was prepared according to the general procedure from aniline and phenylbenzoate. Purification was performed by column chromatography using a mixture of ethyl acetate:hexane (85:15) as eluent, to afford the title product as a white solid (184 mg, 93\%). ${ }^{1} \mathbf{H}-\mathbf{N M R}\left(\mathrm{CDCl}_{3}, 400 \mathrm{MHz}\right): \delta=7.88(\mathrm{~d}, J$ $=1.8 \mathrm{~Hz}, 3 \mathrm{H}), 7.65(\mathrm{~d}, J=7.9 \mathrm{~Hz}, 2 \mathrm{H}), 7.56(\mathrm{t}, J=7.3 \mathrm{~Hz}, 1 \mathrm{H}), 7.49(\mathrm{t}, J=7.68 \mathrm{~Hz}, 1 \mathrm{H}), 7.38(\mathrm{t}, J$ $=8.4 \mathrm{~Hz}, 2 \mathrm{H}), 7.16(\mathrm{t}, J=7.4 \mathrm{~Hz}, 1 \mathrm{H}) .{ }^{13} \mathbf{C}-\mathbf{N M R}\left(\mathrm{CDCl}_{3}, 100 \mathrm{MHz}\right): \delta=166.1,138.3,135.4,132.2$, $129.4,129.1,127.4,124.9,120.1$. Characterization data is consistent with the reported literature. ${ }^{9}$

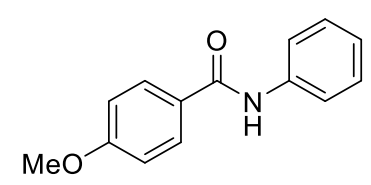

4-methoxy-N-phenylbenzamide (Table 3, entry 2) was prepared according to the general procedure from aniline and phenyl 4-methoxybenzoate. Purification was performed by column chromatography using a mixture of ethyl petroleum ether:ethyl acetate (85:15) as eluent to afford the title product as a white solid (207 
mg, 91\%). ${ }^{1} \mathrm{H}-\mathrm{NMR}\left(\mathrm{CDCl}_{3}, 400 \mathrm{MHz}\right): \delta=7.85$ (d, $\left.J=8.8 \mathrm{~Hz}, 2 \mathrm{H}\right), 7.79$ (brs, $\left.1 \mathrm{H}\right), 7.64$ (d, $J=7.8$ $\mathrm{Hz}, 2 \mathrm{H}), 7.37(\mathrm{t}, J=8.1 \mathrm{~Hz}, 2 \mathrm{H}), 7.14(\mathrm{t}, J=7.4 \mathrm{~Hz}, 1 \mathrm{H}), 6.97(\mathrm{~d}, J=8.7 \mathrm{~Hz}, 2 \mathrm{H}), 3.88(\mathrm{~s}, 3 \mathrm{H}) .{ }^{13} \mathrm{C}-$ NMR $\left(\mathrm{CDCl}_{3}, 100 \mathrm{MHz}\right): \delta=165.5,162.8,138.4,129.4,129.2,127.5,124.7,120.5,114.3,55.8$. Characterization data is consistent with the reported literature. ${ }^{10}$

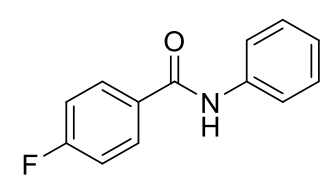

4-fluoro-N-phenylbenzamide (Table 3, entry 3) was prepared according to the general procedure from 4-nitro aniline and phenyl 4-fluorobenzoate. Purification was performed by column chromatography using a mixture of petroleum ether:ethyl acetate $(85: 15)$ as eluent to afford the title product as a white solid (204 mg, 95\%). ${ }^{1} \mathrm{H}-\mathrm{NMR}$ (DMSO-$\left.{ }_{d 6}, 400 \mathrm{MHz}\right): \delta=10.23(\mathrm{~s}, 1 \mathrm{H}), 8.02-8.06(\mathrm{~m}, 2 \mathrm{H}), 7.76(\mathrm{~d}, J=7.7 \mathrm{~Hz}$ 2H), 7.33-7.38 (m, 3H), $7.11(\mathrm{t}, J=7.3 \mathrm{~Hz}, 1 \mathrm{H}) .{ }^{13} \mathbf{C}-\mathbf{N M R}$ (DMSO- $\left.{ }_{-6}, 100 \mathrm{MHz}\right): \delta=164.4,164.0$ $(\mathrm{d}, J C-F=249 \mathrm{~Hz}), 139.0,131.4(\mathrm{~d}, J C-F=3 \mathrm{~Hz}), 130.3(\mathrm{~d}, J C-F=9 \mathrm{~Hz}), 128.5,123.7,120.4,115.3$ $(\mathrm{d}, J C-F=22 \mathrm{~Hz})$. Characterization data is consistent with the reported literature. ${ }^{11}$

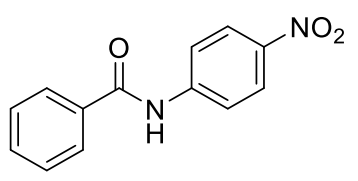

N-(4-nitrophenyl)benzamide (Table 3, entry 4) was prepared according to the general procedure from 4-nitro aniline and phenyl benzoate. Purification was performed by column chromatography using a mixture of petroleum ether:ethyl acetate acetate (70:30) as eluent to afford the title product as a beige solid (197 $\mathrm{mg}, 88$ \%). ${ }^{1}$ H-NMR (DMSO- $d 6,400$ MHz) $\delta 10.81$ (bs, 1H), 8.25-8.29 (m, 2H), 8.06-8.10 (m, 2H), 7.96$8.00(\mathrm{~m}, 2 \mathrm{H}), 7.62-7.66(\mathrm{~m}, 1 \mathrm{H}), 7.54-7.59$ (m, 2H). ${ }^{13} \mathrm{C}-\mathrm{NMR}$ (DMSO- $\left.d 6,100 \mathrm{MHz}\right): \delta=166.3$, $145.5,142.5,134.2,132.2,128.5,127.9,124.8,119.8$. Characterization data is consistent with the reported literature. ${ }^{11}$

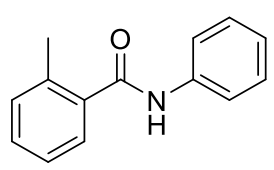

2-methyl-N-phenylbenzamide (Table 3, entry 5) was prepared according to the general procedure fromaniline and phenyl 2-methylbenzoate. Purification was performed by column chromatography using a mixture of petroleum ether:ethyl acetate acetate (70:30) as eluent to afford the title product as a white solid (45 mg, 95\%). ${ }^{1} \mathbf{H}-\mathbf{N M R}$ $\left(\mathrm{CDCl}_{3}, 400 \mathrm{MHz}\right): \delta=7.68$ (brs, $\left.1 \mathrm{H}\right), 7.62(\mathrm{~d}, J=7.6 \mathrm{~Hz}, 2 \mathrm{H}), 7.45(\mathrm{~d}, J=7.4 \mathrm{~Hz}, 1 \mathrm{H}), 7.36(\mathrm{t}, J=$ 7.6 Hz, 3H), 7.21-7.27 (m, 2H), 7.16 (t, $J=7.4 \mathrm{~Hz}, 1 \mathrm{H}), 2.45$ (s, 3H). ${ }^{13} \mathbf{C}-\mathbf{N M R}\left(\mathrm{CDCl}_{3}, 100 \mathrm{MHz}\right)$ : $\delta=168.4,138.3,136.7,136.7,131.5,130.5,129.4,126.9,126.2,124.8,120.2$, 20.1. Characterization data is consistent with the reported literature. ${ }^{12}$

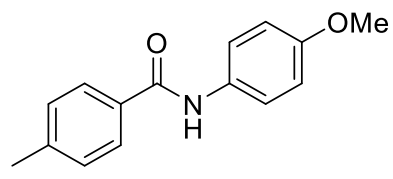

N-(4-methoxyphenyl)-4-methylbenzamide (Table 3, entry 6) was prepared according to the general procedure from 4-methoxyaniline and phenyl benzoate. Purification was performed by column 
chromatography using a mixture of ethyl petroleum ether:ethyl acetate $(85: 15)$ as eluent to afford the title product as beige solid (219 mg, 90\%). ${ }^{1} \mathbf{H}-\mathbf{N M R}\left(\mathrm{CDCl}_{3}, 400 \mathrm{MHz}\right): \delta=7.75-7.79(\mathrm{~m}, 3 \mathrm{H}), 7.53$ $(\mathrm{d}, J=8.8 \mathrm{~Hz}, 2 \mathrm{H}), 7.27(\mathrm{~d}, J=7.7 \mathrm{~Hz}, 2 \mathrm{H}), 6.90(\mathrm{~d}, J=8.9 \mathrm{~Hz}, 2 \mathrm{H}), 3.82(\mathrm{~s}, 3 \mathrm{H}), 2.43(\mathrm{~s}, 3 \mathrm{H}) .{ }^{13} \mathbf{C}-$ NMR $\left(\mathrm{CDCl}_{3}, 100 \mathrm{MHz}\right): \delta=165.9,156.9,142.5,132.5,131.4,129.7,127.3,122.4,114.5,55.8$, 21.8. Characterization data is consistent with the reported literature. ${ }^{13}$

General procedure for the Suzuki-Miyarura coupling of amides and boronic acids.

In a Schlenk flask were charged sequentially the amide substrate $(1.0 \mathrm{mmol})$, potassium carbonate (3.0 mmol), boronic acid $(2.0 \mathrm{mmol})$ and the catalyst $(3 \mathrm{~mol} \%)$. Under nitrogen, dry THF (5 mL) was added with vigorous stirring at room temperature and then heated at $60{ }^{\circ} \mathrm{C}$ for $12 \mathrm{~h}$. The reaction mixture was cooled down to room temperature, diluted with $\mathrm{CH}_{2} \mathrm{Cl}_{2}(10 \mathrm{~mL})$, filtered, and concentrated. Purification by chromatography on silica gel (EtOAc/hexanes) afforded the desired product.

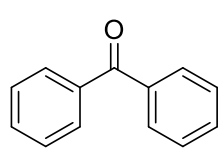

Benzophenone (Table 4, entry 1): The general procedure afforded the title compound in $92 \%$ (168 mg, white solid) isolated yield after column chromatography using a mixture of 25:75 ethyl acetate/hexane as eluent $\left(R_{f}=0.61\right) .{ }^{1} H-N M R$ $\left(\mathrm{CDCl}_{3}, 400 \mathrm{MHz}\right): \delta=7.47-7.50(\mathrm{~m}, 4 \mathrm{H}, \mathrm{ArH}), 7.57-7.61(\mathrm{~m}, 2 \mathrm{H}, \mathrm{ArH}), 7.81(\mathrm{~d}, J=7.8 \mathrm{~Hz}, 4 \mathrm{H}$, $\mathrm{ArH}) .{ }^{13} \mathrm{C}-\mathrm{NMR}\left(\mathrm{CDCl}_{3}, 100 \mathrm{MHz}\right): \delta=196.8,137.6,132.4,130.1,128.3$. Spectroscopy data is consistent with the literature. ${ }^{7}$

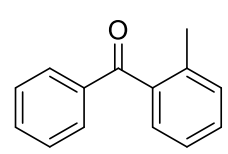

2-Methylbenzophenone (Table 4, entry 2): The general procedure afforded the title compound in $97 \%$ (190 mg, clear oil) isolated yield after column chromatography using a mixture of 15:85 ethyl acetate/hexane as eluent $\left(\mathrm{R}_{\mathrm{f}}=0.57\right) .{ }^{1} \mathrm{H} \mathrm{NMR}\left(\mathrm{CDCl}_{3}\right.$, $400 \mathrm{MHz}): \delta=7.83(\mathrm{~d}, J=7.6 \mathrm{~Hz}, 2 \mathrm{H}, \operatorname{Ar} H), 7.61(\mathrm{t}, J=7.3 \mathrm{~Hz}, 1 \mathrm{H}, \operatorname{Ar} H), 7.48(\mathrm{t}, J=7.4 \mathrm{~Hz}, 2 \mathrm{H}$, $\operatorname{Ar} H), 7.42(\mathrm{t}, J=7.4 \mathrm{~Hz}, 1 \mathrm{H}, \operatorname{Ar} H), 7.33(\mathrm{t}, J=9.4 \mathrm{~Hz}, 2 \mathrm{H}, \operatorname{Ar} H), 7.28(\mathrm{~d}, J=5.9 \mathrm{~Hz}, 1 \mathrm{H}, \operatorname{Ar} H)$, $2.36\left(\mathrm{~s}, 3 \mathrm{H}, \mathrm{CH}_{3}\right) .{ }^{13} \mathrm{C} \mathrm{NMR}\left(100 \mathrm{MHz}, \mathrm{CDCl}_{3}\right): \delta=198.7,138.6,137.8,136.8,133.2,131.0,130.3$, $130.2,128.5,128.5,125.2,20.0$. Spectroscopy data is consistent with the literature. ${ }^{7}$

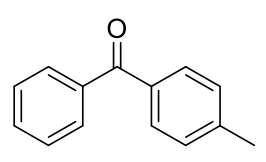

4-Methylbenzophenone (Table 4, entry 3): The general procedure afforded the title compound in 93\% (181 mg, off white solid) isolated yield after column chromatography using a mixture of 10:90 ethyl acetate/hexane as eluent $\left(\mathrm{R}_{\mathrm{f}}=\right.$ 0.55). ${ }^{1} \mathrm{H} \mathrm{NMR}\left(\mathrm{CDCl}_{3}, 400 \mathrm{MHz}\right): \delta=7.79(\mathrm{~d}, J=7.5 \mathrm{~Hz}, 2 \mathrm{H}, \mathrm{ArH}), 7.72(\mathrm{~d}, J=7.4 \mathrm{~Hz}, 2 \mathrm{H}, \operatorname{Ar} H)$, $7.58(\mathrm{t}, J=7.3 \mathrm{~Hz}, 1 \mathrm{H}, \operatorname{Ar} H), 7.47(\mathrm{t}, J=7.4 \mathrm{~Hz}, 2 \mathrm{H}, \operatorname{Ar} H), 7.28(\mathrm{~d}, J=7.6 \mathrm{~Hz}, 2 \mathrm{H}, \operatorname{Ar} H), 2.44(\mathrm{~s}$, 
$\left.3 \mathrm{H}, \mathrm{CH}_{3}\right) .{ }^{13} \mathrm{C} \mathrm{NMR}\left(100 \mathrm{MHz}, \mathrm{CDCl}_{3}\right) \delta=196.5,143.3,138.0,134.9,132.2,130.3,130.0,129.0$, 128.2, 21.7. Spectroscopy data is consistent with the literature. ${ }^{7}$

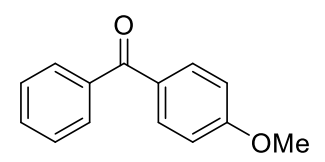

4-Methoxybenzophenone (Table 4, entry 4): The general procedure afforded the title compound in $95 \%$ ( $202 \mathrm{mg}$, off white solid) isolated yield after column chromatography using a mixture of 10:80 ethyl acetate/hexane as eluent $\left(\mathrm{R}_{\mathrm{f}}=\right.$ 0.37). ${ }^{1} \mathrm{H}-\mathrm{NMR}\left(\mathrm{CDCl}_{3}, 400 \mathrm{MHz}\right): \delta=7.83(\mathrm{~d}, J=8.4 \mathrm{~Hz}, 2 \mathrm{H}, \mathrm{Ar} H), 7.76(\mathrm{~d}, J=7.5 \mathrm{~Hz}, 2 \mathrm{H}, \operatorname{Ar} H)$, $7.56(\mathrm{t}, J=7.3 \mathrm{~Hz}, 1 \mathrm{H}, \operatorname{Ar} H), 7.47(\mathrm{t}, J=7.3 \mathrm{~Hz}, 2 \mathrm{H}, \operatorname{Ar} H), 6.97(\mathrm{~d}, J=8.4 \mathrm{~Hz}, 2 \mathrm{H}, \operatorname{Ar} H), 3.89(\mathrm{~s}$, $\left.3 \mathrm{H}, \mathrm{OCH}_{3}\right) .{ }^{13} \mathrm{C} \mathrm{NMR}\left(100 \mathrm{MHz}, \mathrm{CDCl}_{3}\right): \delta=195.6,163.2,138.3,132.6,131.9,130.2,129.8,128.2$, 113.6, 55.5. Spectroscopy data is consistent with the literature. ${ }^{7}$

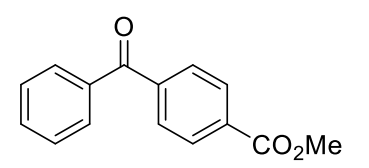

4-Acetatebenzophenone (Table 4, entry 5): The general procedure afforded the title compound in $91 \%$ ( $218 \mathrm{mg}$, white solid) isolated yield after column chromatography using a mixture of 10:90 ethyl acetate/hexane as eluent $\left(\mathrm{R}_{\mathrm{f}}\right.$ $=0.41) .{ }^{1} \mathrm{H}-\mathrm{NMR}\left(\mathrm{CDCl}_{3}, 400 \mathrm{MHz}\right): \delta=8.15(\mathrm{~d}, J=8.2 \mathrm{~Hz}, 2 \mathrm{H}, \mathrm{ArH}), 7.83(\mathrm{~d}, J=8.2 \mathrm{~Hz}, 2 \mathrm{H}$, $\operatorname{Ar} H), 7.81(\mathrm{~d}, J=7.8 \mathrm{~Hz}, 2 \mathrm{H}, \operatorname{Ar} H), 7.62(\mathrm{t}, J=7.5 \mathrm{~Hz}, 1 \mathrm{H}, \operatorname{Ar} H), 7.51(\mathrm{t}, J=7.5 \mathrm{~Hz}, 2 \mathrm{H}, \operatorname{Ar} H)$, 3.97 (s, 3H, $\left.\mathrm{CH}_{3}\right) .{ }^{13} \mathrm{C} \mathrm{NMR}\left(100 \mathrm{MHz}, \mathrm{CDCl}_{3}\right): \delta=196.1,166.3,141.3,137.0,133.2,133.1,130.0$, $129.8,129.5,128.5,52.6$. Spectroscopy data is consistent with the literature. ${ }^{7}$

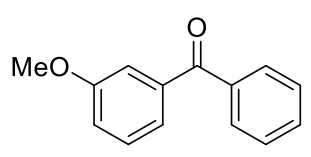

3-Methoxybenzophenone (Table 4, entry 6): The general procedure afforded the title compound in $92 \%$ (194 $\mathrm{mg}$, white solid) isolated yield after column chromatography using a mixture of 15:85 ethyl acetate/hexane as eluent $\left(\mathrm{R}_{\mathrm{f}}=\right.$ 0.39). ${ }^{1} \mathrm{H}-\mathrm{NMR}\left(\mathrm{CDCl}_{3}, 400 \mathrm{MHz}\right): \delta=7.82(\mathrm{~d}, J=7.7 \mathrm{~Hz}, 2 \mathrm{H}, \mathrm{Ar} H), 7.59$ (t, $\left.J=7.5 \mathrm{~Hz}, 1 \mathrm{H}, \operatorname{Ar} H\right)$, 7.49 (t, $J=7.5 \mathrm{~Hz}, 2 \mathrm{H}, \mathrm{ArH}), 7.40-7.33$ (m, 3H, ArH), 7.15 (d, $J=7.2 \mathrm{~Hz}, 1 \mathrm{H}, \operatorname{Ar} H), 3.86(\mathrm{~s}, 3 \mathrm{H}$, $\left.\mathrm{OCH}_{3}\right) .{ }^{13} \mathrm{C} \mathrm{NMR}\left(100 \mathrm{MHz}, \mathrm{CDCl}_{3}\right) \delta=196.6,159.5,139.0,137.7,132.3,130.1,129.2,128.3$, $122.9,118.9,114.2,55.6$. Spectroscopy data is consistent with the literature. ${ }^{7}$

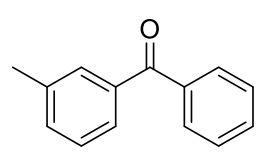

3-Methylbenzophenone (Table 4, entry 7): The general procedure afforded the title compound in 96\% (188 mg, colorless oil) isolated yield after column chromatography using a mixture of 5:95 ethyl acetate/hexane as eluent. ${ }^{1} \mathrm{H}-\mathrm{NMR}$ $\left(\mathrm{CDCl}_{3}, 400 \mathrm{MHz}\right): \delta=7.81-7.79(\mathrm{~m}, 2 \mathrm{H}, \mathrm{ArH}), 7.63(\mathrm{~s}, 1 \mathrm{H}, \mathrm{ArH}), 7.62-7.59(\mathrm{~m}, 2 \mathrm{H}, \mathrm{ArH}), 7.48$ $(\mathrm{t}, J=7.8 \mathrm{~Hz}, 2 \mathrm{H}, \mathrm{ArH}), 7.42-7.37(\mathrm{~m}, 2 \mathrm{H}, \mathrm{ArH}), 2.43\left(\mathrm{~s}, 3 \mathrm{H}, \mathrm{CH}_{3}\right) \cdot{ }^{13} \mathrm{C} \mathrm{NMR}\left(100 \mathrm{MHz}, \mathrm{CDCl}_{3}\right) \delta$ $=197.1,138.2,137.8,137.8,133.2,132.3,130.5,130.1,128.3,128.1,127.4,21.3$. Spectroscopy data is consistent with the literature. ${ }^{8}$ 
NC

4-Cyanobenzophenone (Table 4, entry 8 ): The general procedure afforded the title compound in $88 \%$ (182 $\mathrm{mg}$, off white oil) isolated yield after column chromatography using a mixture of 10:90 ethyl acetate/hexane as eluent $\left(\mathrm{R}_{\mathrm{f}}=\right.$ 0.63). ${ }^{1} \mathrm{H}-\mathrm{NMR}\left(\mathrm{CDCl}_{3}, 400 \mathrm{MHz}\right): \delta=7.88(\mathrm{~d}, J=7.8 \mathrm{~Hz}, 2 \mathrm{H}, \mathrm{ArH}), 7.82-7.74(\mathrm{~m}, 4 \mathrm{H}, \mathrm{Ar} H), 7.64$ $(\mathrm{t}, J=7.3 \mathrm{~Hz}, 1 \mathrm{H}, \mathrm{Ar} H), 7.52(\mathrm{t}, J=7.3 \mathrm{~Hz}, 2 \mathrm{H}, \mathrm{Ar} H) .{ }^{13} \mathrm{C} \mathrm{NMR}\left(100 \mathrm{MHz}, \mathrm{CDCl}_{3}\right) \delta=195.1,141.3$, $136.4,133.4,132.2,130.3,130.1,128.7,118.0,115.5$. Spectroscopy data is consistent with the literature. $^{7}$

General procedure for the catalytic hydrosilylation reactions.

In a thick-called Schlenk flask under nitrogen atmosphere were added complex 3, triethyl silane (19 $\mu \mathrm{L}, 0.117 \mathrm{mmol})$, phenyl acetylene $(11 \mu \mathrm{L}, 0.098 \mathrm{mmol})$ and $3 \mathrm{~mL}$ of dry solvent. The mixture was stirred and heated at $110^{\circ} \mathrm{C}$ for 24 hours. After reaching the room temperature, the solution is filtrated and analysed by NMR spectroscopy.

\section{Catalytic poisoning tests}

Coupling of 2-methyl phenylboronic acid with 2-methyl-chlorobenzene catalyzed by 2 and 3.

Mercury poisoning tests. To the reaction mixture of the appropriate catalyst (1 mol\%), sodium tertbutoxide $(1.5 \mathrm{mmol})$, boronic acid $(1.2 \mathrm{mmol})$ and 2-methyl-chlorobenzene $(1.0 \mathrm{mmol})$ in $5 \mathrm{~mL}$ of dry dioxane was added an excess amount of $\mathrm{Hg}(5 \mathrm{mmol})$ at the beginning of the reaction. Aliquots $(\sim 10 \mu \mathrm{L})$ were removed every 15 minutes and analyzed by gas chromatography.

DCT (dibenzo[a,e]cyclooctatriene) poisoning tests. To the reaction mixture of the appropriate catalyst $(1 \mathrm{~mol} \%)$, sodium tert-butoxide $(1.5 \mathrm{mmol})$, boronic acid $(1.2 \mathrm{mmol})$ and 2-methylchlorobenzene $(1.0 \mathrm{mmol})$ in $5 \mathrm{~mL}$ of dry dioxane was added a slight excess amount of DCT (1.5 $\mathrm{mmol})$ at at the beginning of the reaction. Aliquots $(\sim 10 \mu \mathrm{L})$ were removed every 15 minutes and analyzed by gas chromatography.

Suzuki-Miyaura cross coupling of amides catalyzed by 2 and $\mathbf{3}$.

Mercury poisoning tests. To the reaction mixture of the appropriate catalyst (3 mol\%), potassium carbonate $(3 \mathrm{mmol})$, boronic acid $(2.0 \mathrm{mmol})$ and the amide $(1 \mathrm{mmol})$ in $5 \mathrm{~mL}$ of dry THF was added an excess amount of $\mathrm{Hg}(5 \mathrm{mmol})$ at different reaction times $(\mathrm{t}=0,2,4$ and $6 \mathrm{~h})$. After addition of elemental mercury, every reaction mixture was heated at $60^{\circ} \mathrm{C}$ for $14 \mathrm{~h}$. Aliquots $(\sim 10 \mu \mathrm{L})$ were removed every 2 hours and analyzed by gas chromatography.

DCT (dibenzo[a,e]cyclooctatriene) poisoning tests. To the reaction mixture of the appropriate catalyst ( $3 \mathrm{~mol} \%)$, potassium carbonate $(3 \mathrm{mmol})$, boronic acid $(2.0 \mathrm{mmol})$ and the amide $(1 \mathrm{mmol})$ in $5 \mathrm{~mL}$ of dry THF was added an excess of DCT $(1.5 \mathrm{mmol})$ at the beginning of the reaction. After 
the addition of DTC every reaction mixture was heated at $60^{\circ} \mathrm{C}$ for $14 \mathrm{~h}$. Aliquots $(\sim 10 \mu \mathrm{L})$ were removed every $2 \mathrm{~h}$ and analyzed by gas chromatography.

Cross coupling reaction of esters for benzylamide preparation under catalytic 2 and $\mathbf{3}$

Mercury poisoning tests. To the reaction mixture of the appropriate catalyst ( $3 \mathrm{~mol} \%$ ), potassium carbonate $(1.2 \mathrm{mmol})$, ester $(1.0 \mathrm{mmol})$ and aniline $(1.2 \mathrm{mmol})$ in $5 \mathrm{~mL}$ of dry toluene was added an excess amount of $\mathrm{Hg}(5 \mathrm{mmol})$ at different reaction times $(\mathrm{t}=0,2,6$ and $8 \mathrm{~h})$. After addition of elemental mercury, every reaction mixture was heated at $80^{\circ} \mathrm{C}$ for $18 \mathrm{~h}$. Aliquots $(\sim 10 \mu \mathrm{L})$ were removed every $2 \mathrm{~h}$ and analyzed by gas chromatography.

DCT (dibenzo[a,e]cyclooctatriene) poisoning tests. To the reaction mixture of the appropriate catalyst (3 mol\%), potassium carbonate $(1.2 \mathrm{mmol})$, ester $(1.0 \mathrm{mmol})$ and aniline $(1.2 \mathrm{mmol})$ in $5 \mathrm{~mL}$ of dry toluene was added an excess amount of DCT $(1.5 \mathrm{mmol})$ at the beginning of the reaction. After the addition of DTC every reaction mixture was heated at $80^{\circ} \mathrm{C}$ for $18 \mathrm{~h}$. Aliquots $(\sim 10 \mu \mathrm{L})$ were removed every $2 \mathrm{~h}$ and analyzed by gas chromatography.

\section{References:}

1) M. C. Lukowiak, M. Meise and R. Haag, Synlett 2014, 25, 2161. (b) C. Lang, K. Pahnke, C. Kiefer, A. S. Goldmann, P. W. Roesky and C. Barner-Kowollik, Polym. Chem. 2013, 4, 5456. (c) H. Li, L.-Y. Jin and R.-J. Tao, Acta Crystallogr., Sect. E: Struct. Rep Online 2008, 64, o900

2) (a) D. Mendoza-Espinosa, G. E. Negron-Silva, L. Lomas- Romero, A. Gutierrez-Carrillo and D. Soto-Castro, Synthesis, 2013, 2431. (b) D. Mendoza-Espinosa, G. E. NegronSilva, L. Lomas-Romero, A. Gutierrez-Carrillo and R. Santillan, Synth. Commun., 2013, 44, 807.

3) G. M. Sheldrick, SHELXS-2014, Program for Crystal Structure Solution and Refinement; Institut Für Anorganishe Chemie, Göttingen, $\quad$ Germany, 2013.

4) Chen, M.-T; Kao, Z.-L. Dalton Trans., 2017, 46, 16394.

5) Terao, Y.; Wakui, H.; Satoh, T.; Miura, M.; Nomura, M. J. Am. Chem. Soc. 2001, 123, 10407.

6) Wolfe, J. P.; Singer, R. A.; Yang, B. H.; Buchwald, S. L. J. Am. Chem. Soc. 1999, 121, 9550.

7) Meng, G.; Szostak, M. Org. Lett., 2015, 17, 4364.

8) Weires, N. A.; Baker, E. L.; Garg, N. K. Nat. Chem., 2015, 8, 75.

9) Z.-F. Xu, T. Zhang, W. Hong, Tetrahedron, 2019, 75, 3113.

10) S.-M. Wang, C. Zhao, X. Zhang, H-.L. Qin, Org. Biomol. Chem., 2019, 17, 4087.

11) T. B. Halima, J. K. Vandavasi, M. Schkoor, S. G. Newman, ACS Catal., 2017, 7, 2176.

12) L. Ling, C. Chen, M. Luo, X. Zeng, Org. Lett., 2019, 21, 1912.

13) A. H. Dardir, P. R. Melvin, R. M. Davis, N. Hazari, M. Mohadjer Beroni, J. Org. Chem. 2018, 83, 469. 


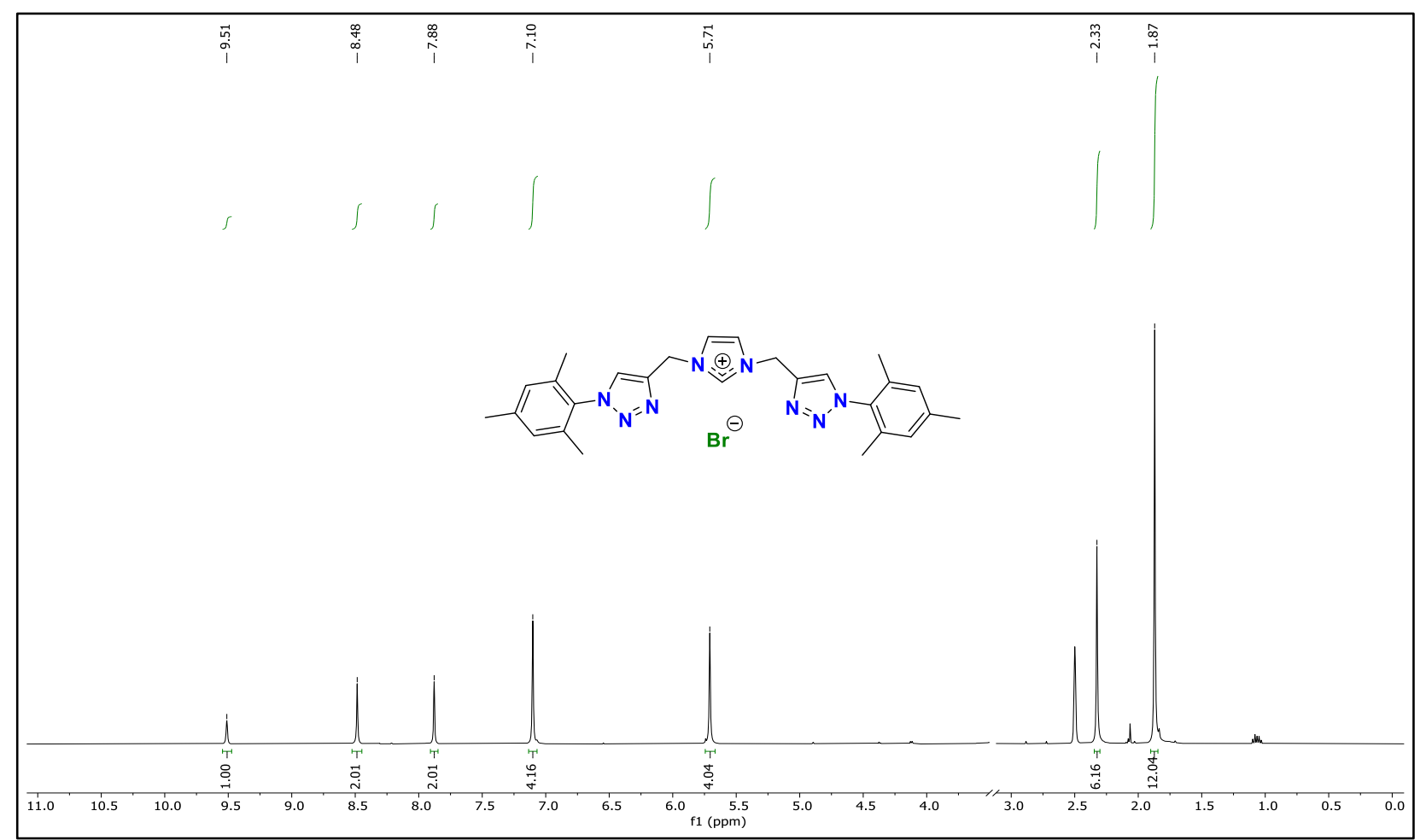

Figure S1. ${ }^{1} \mathrm{H}$ NMR $(400 \mathrm{MHz})$ spectrum of $\mathbf{B}$ in DMSO- $d_{6}$.

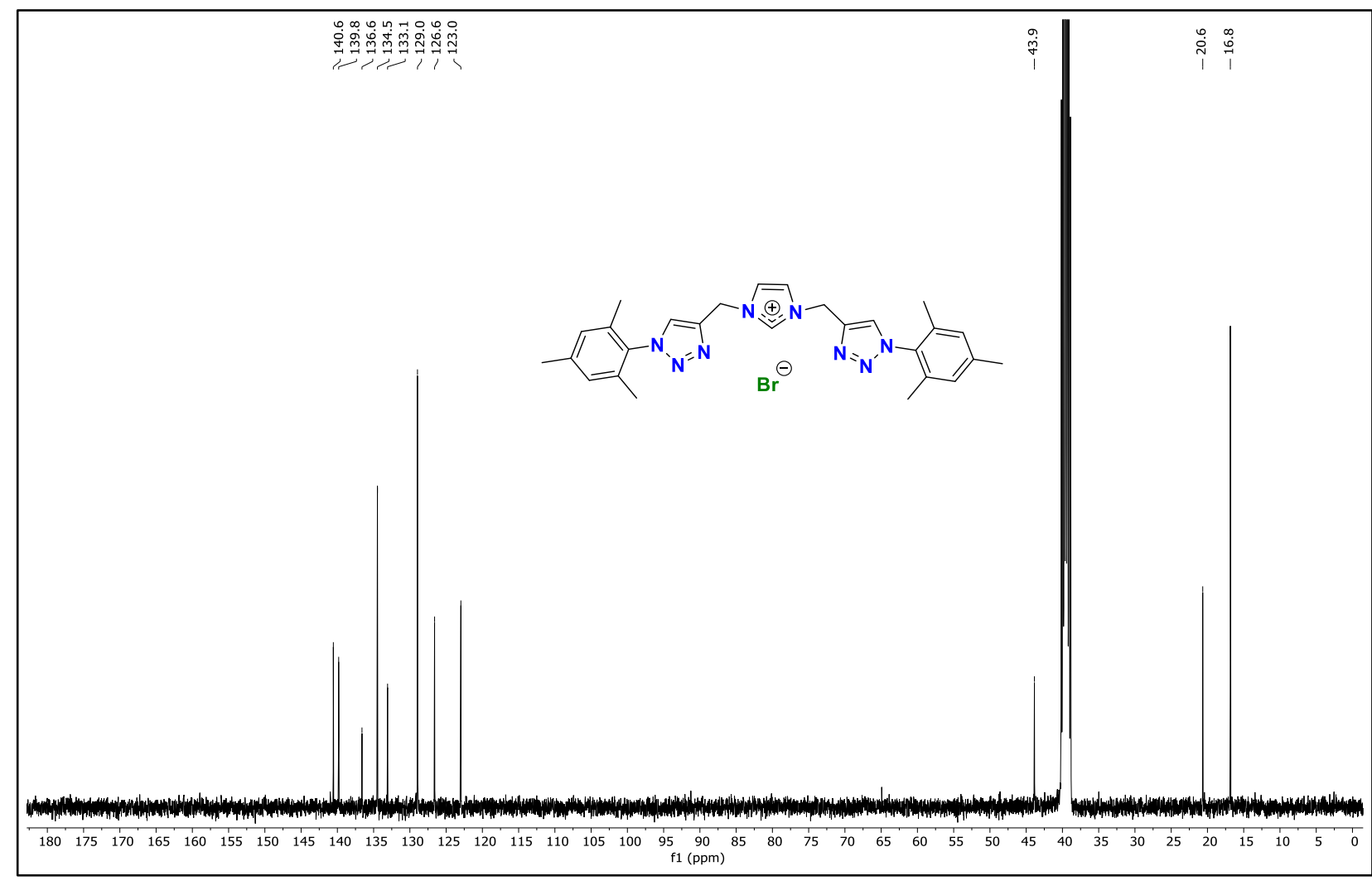

Figure S2. ${ }^{13} \mathrm{C}$ NMR $(100 \mathrm{MHz})$ spectrum of $\mathbf{B}$ in DMSO- $d_{6}$. 


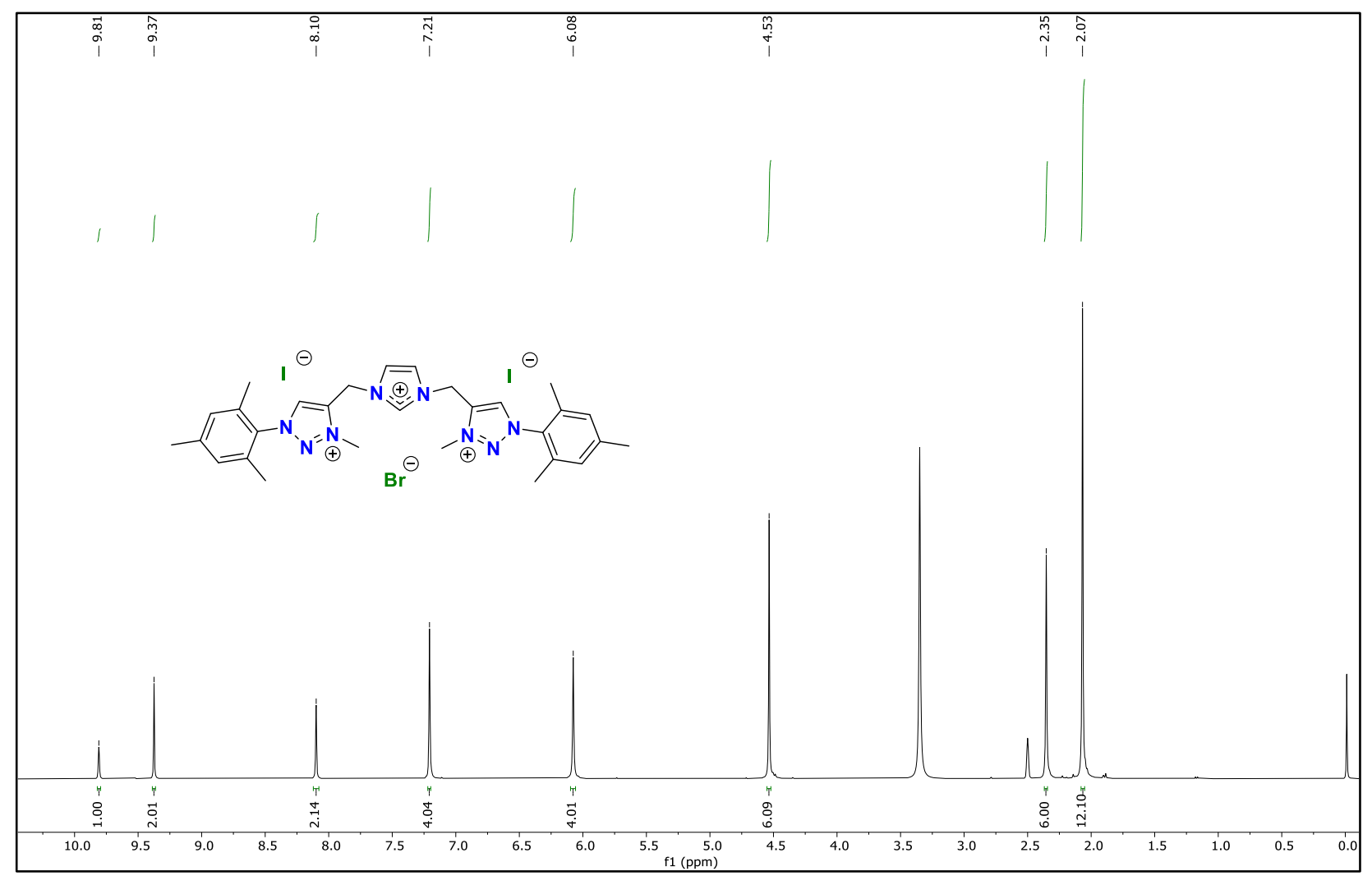

Figure S3. ${ }^{1} \mathrm{H}$ NMR $(400 \mathrm{MHz})$ spectrum of 1 in DMSO- $d_{6}$.

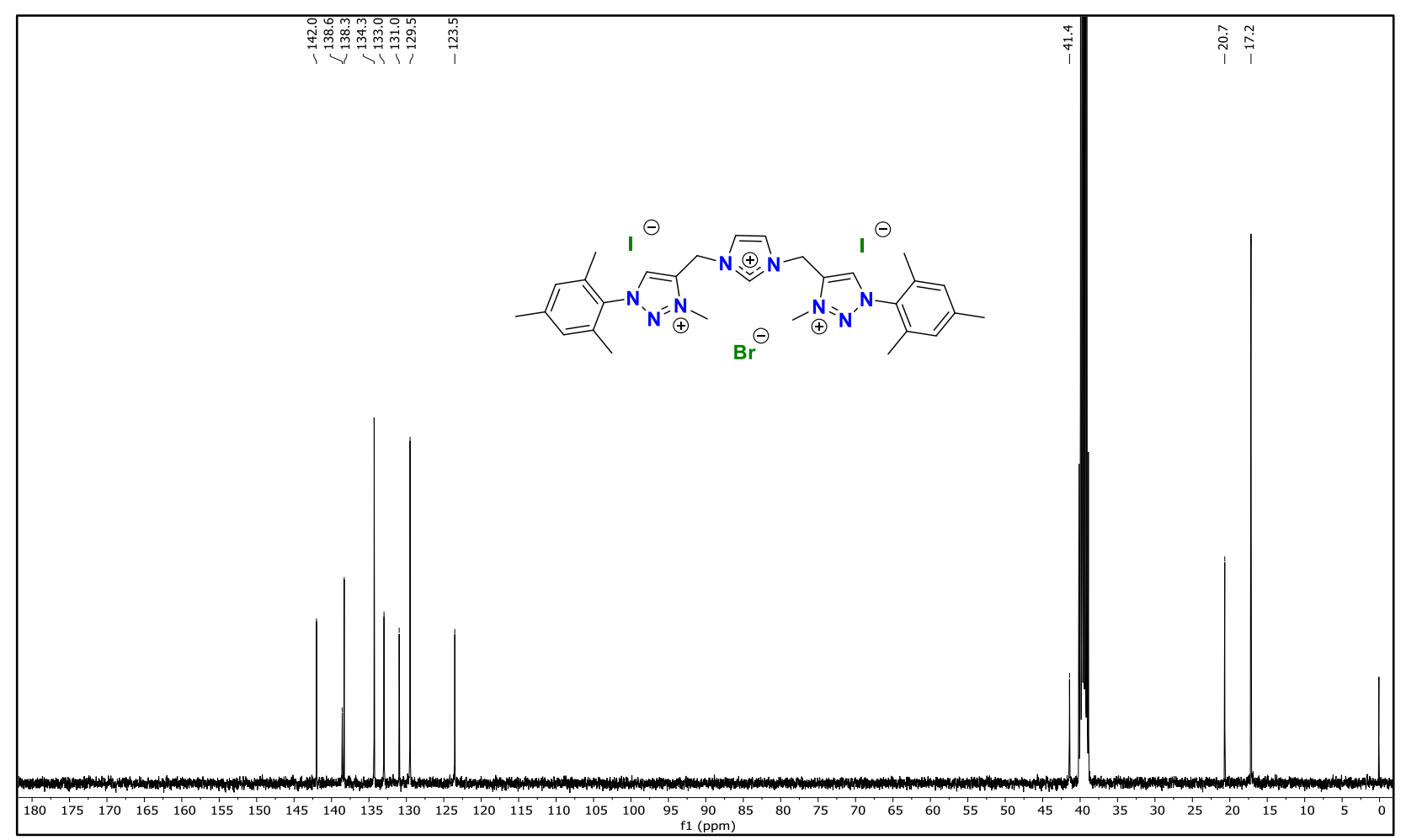

Figure S4. ${ }^{13} \mathrm{C}$ NMR $(100 \mathrm{MHz})$ spectrum of 1 in DMSO- $d_{6}$. 


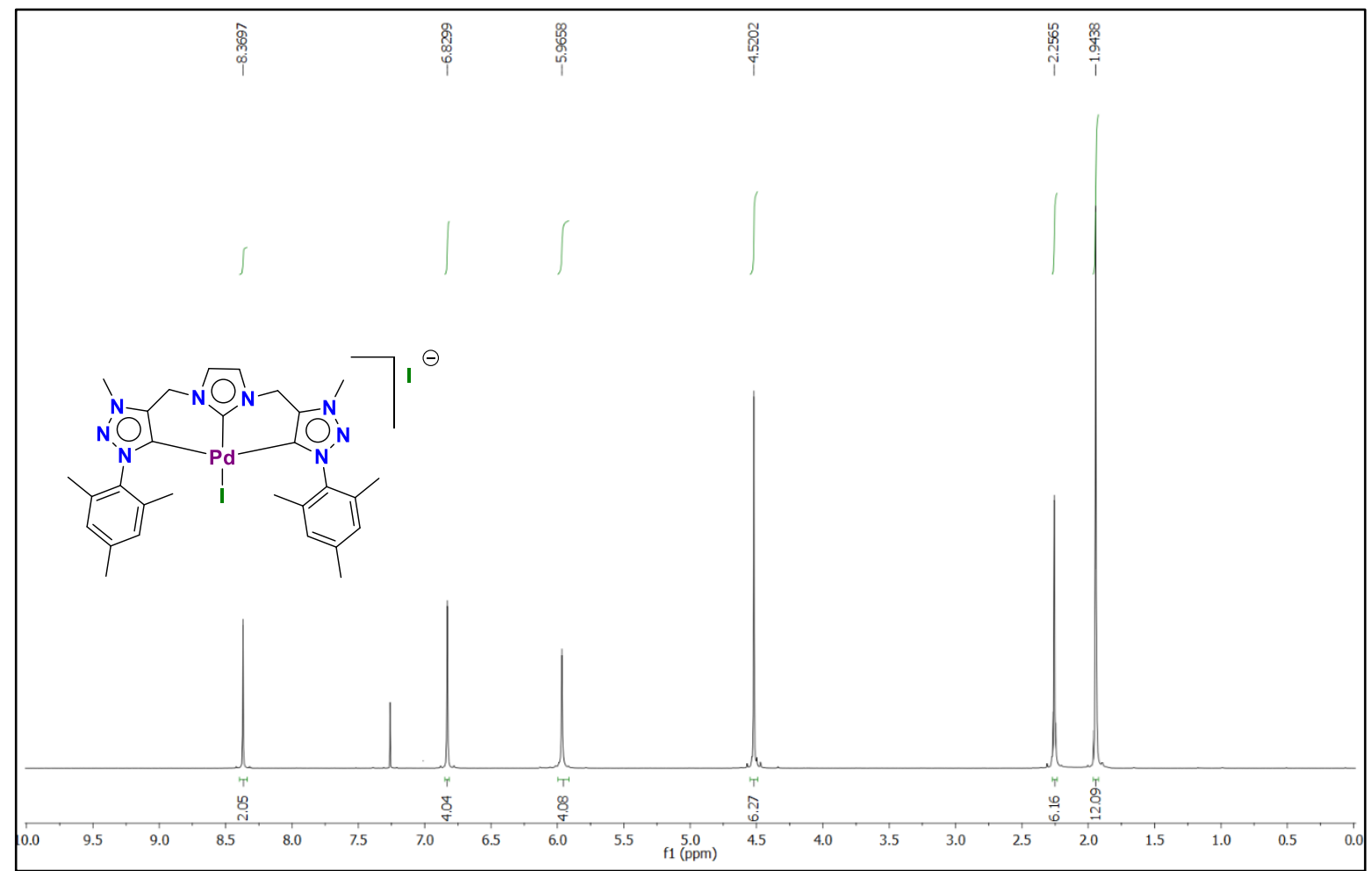

Figure S5. ${ }^{1} \mathrm{H}$ NMR (400 MHz) spectrum of complex 2 in $\mathrm{CDCl}_{3}$.

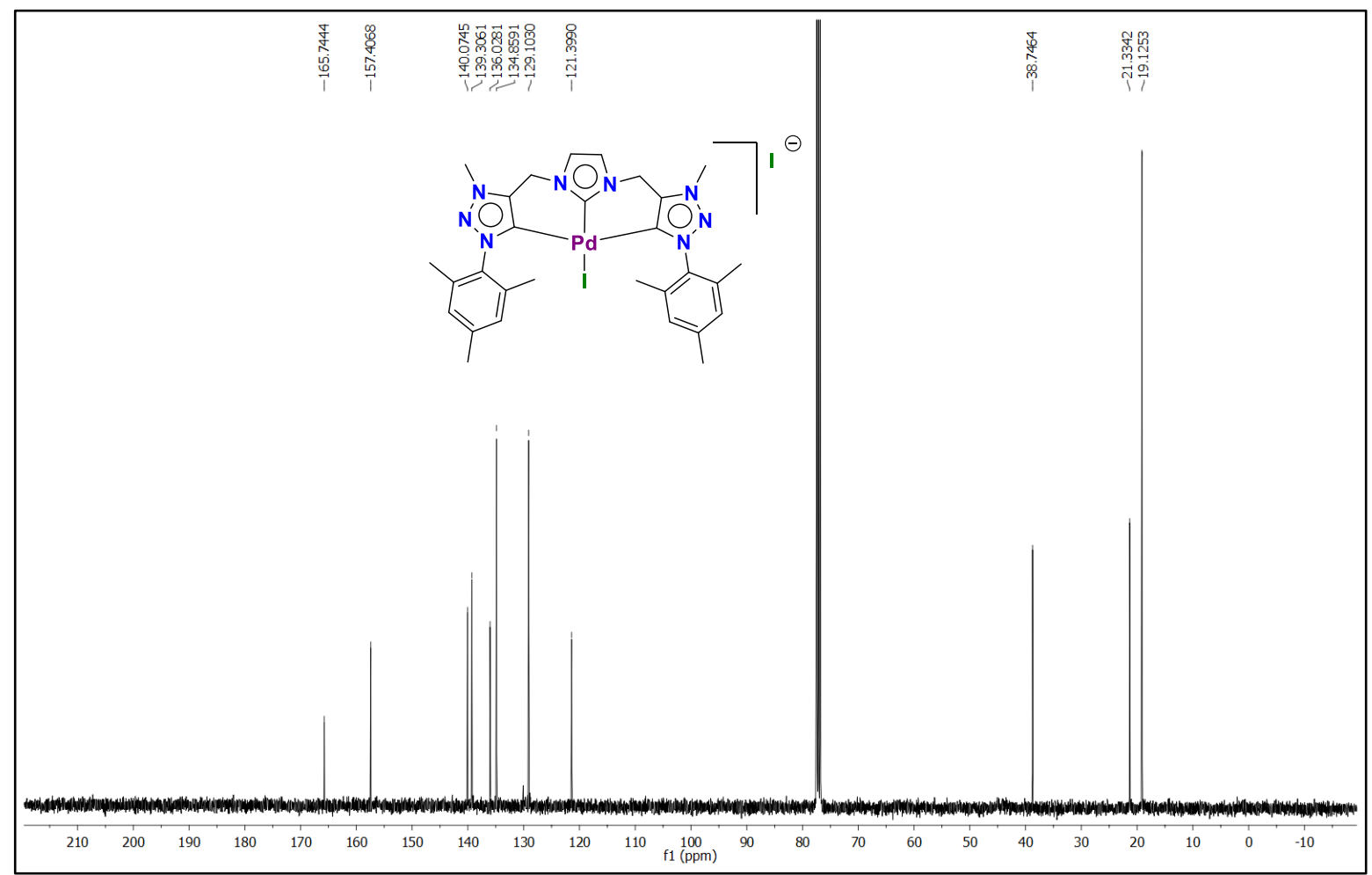

Figure 1. ${ }^{13} \mathrm{C}$ NMR $(100 \mathrm{MHz})$ spectrum of complex 2 in $\mathrm{CDCl}_{3}$. 


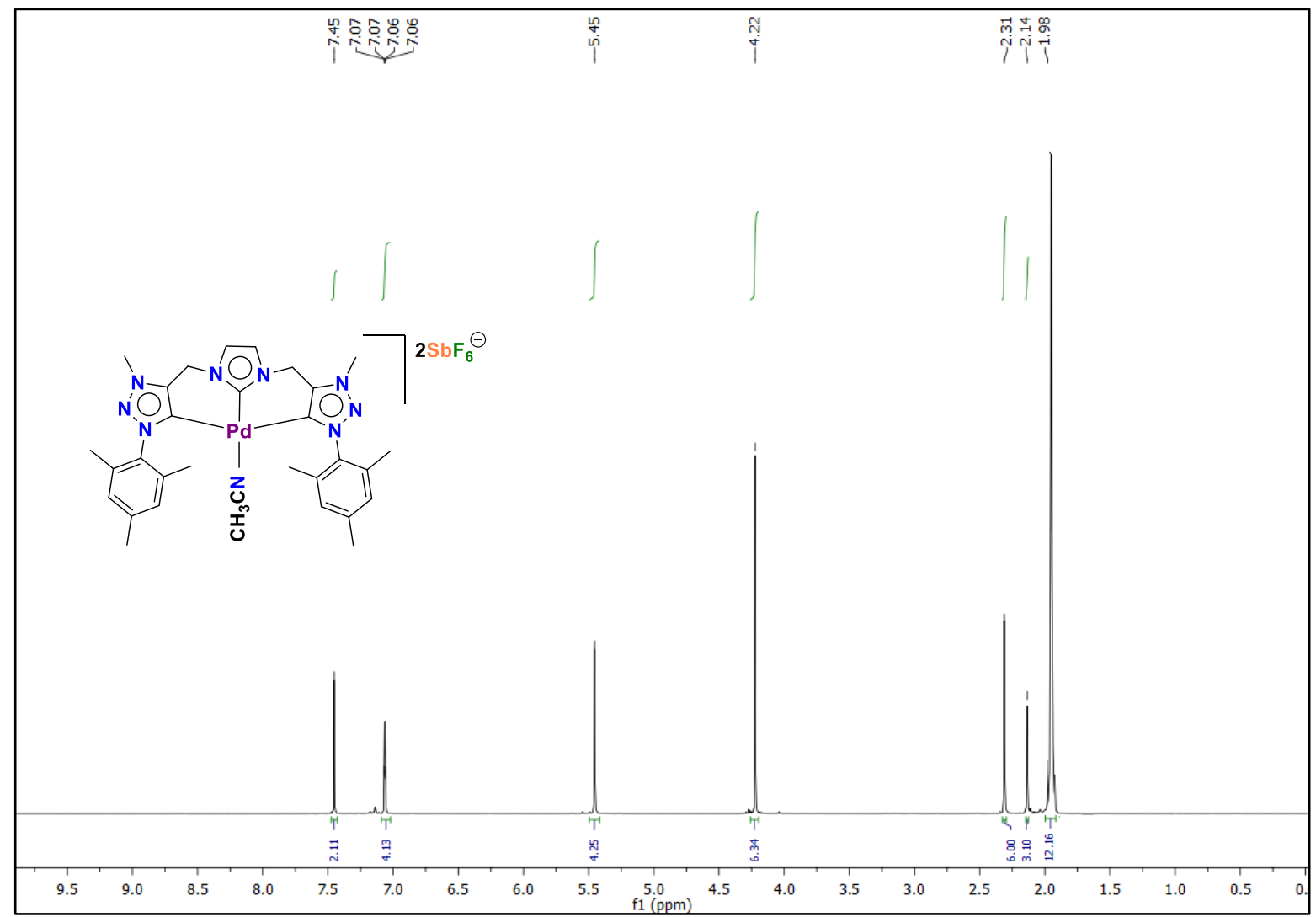

Figure S7. ${ }^{1} \mathrm{H}$ NMR $(100 \mathrm{MHz})$ spectrum of complex 3 in $\mathrm{CD}_{3} \mathrm{CN}$.

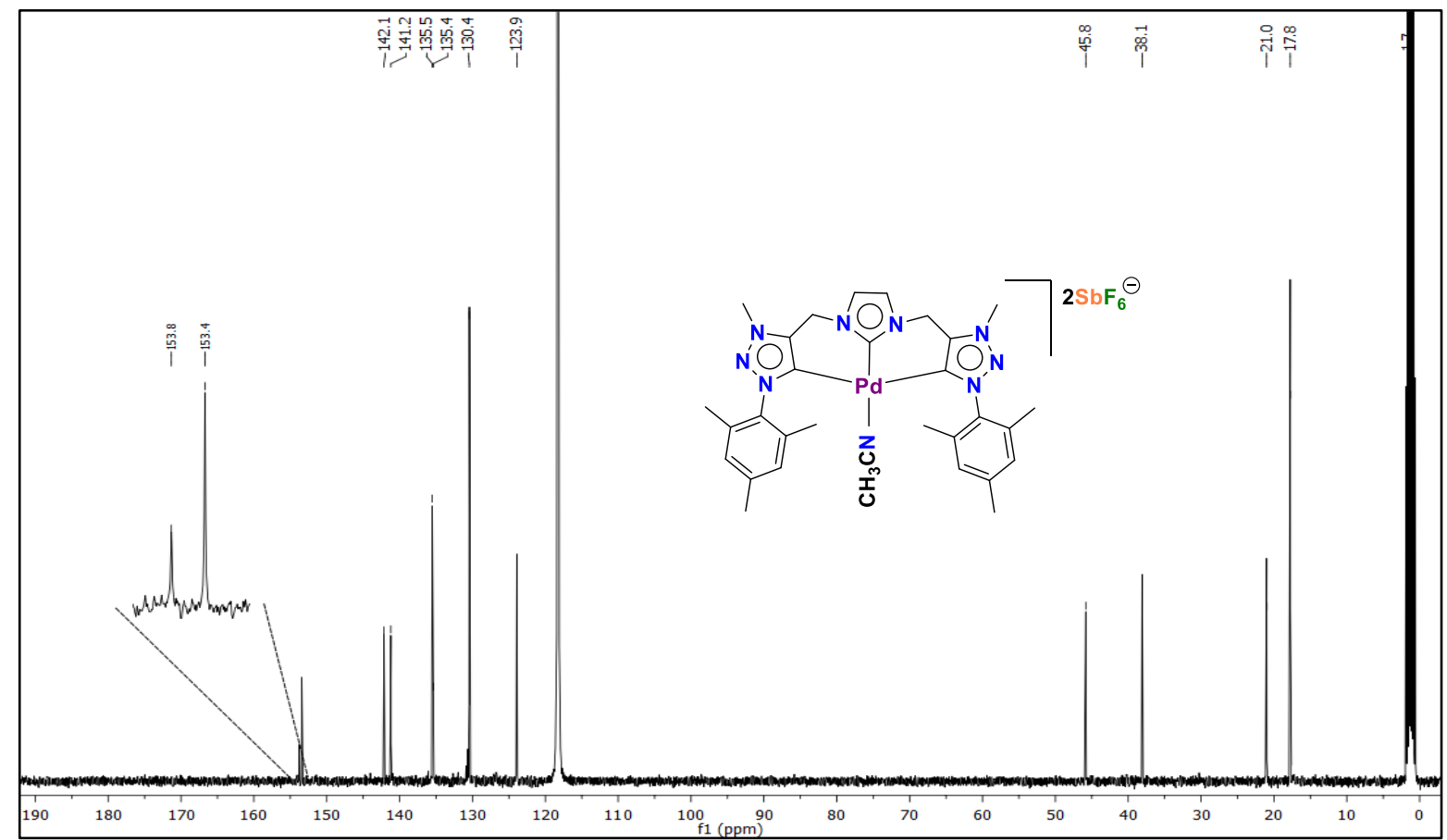

Figure 8. ${ }^{13} \mathrm{C}$ NMR $(400 \mathrm{MHz})$ spectrum of complex 3 in $\mathrm{CD}_{3} \mathrm{CN}$. 


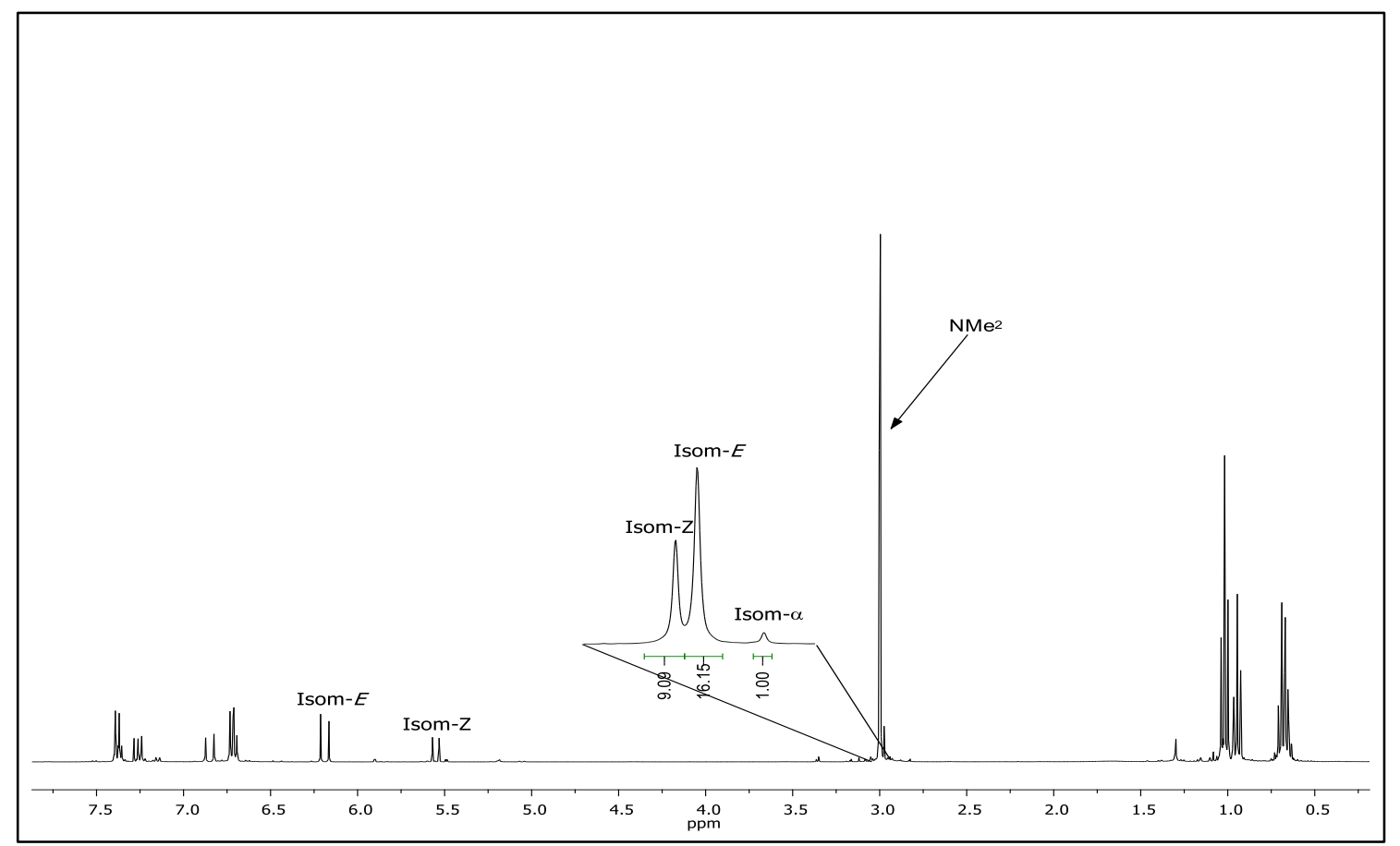

Figure S9. ${ }^{1} \mathrm{H}-\mathrm{NMR}$ spectrum $\left(400 \mathrm{MHz}, \mathrm{CDCl}_{3}\right)$ of the hydrosylation of 4-ethynyl-N,Ndimethylamine with triethylsilane using complex 2 as catalyst.

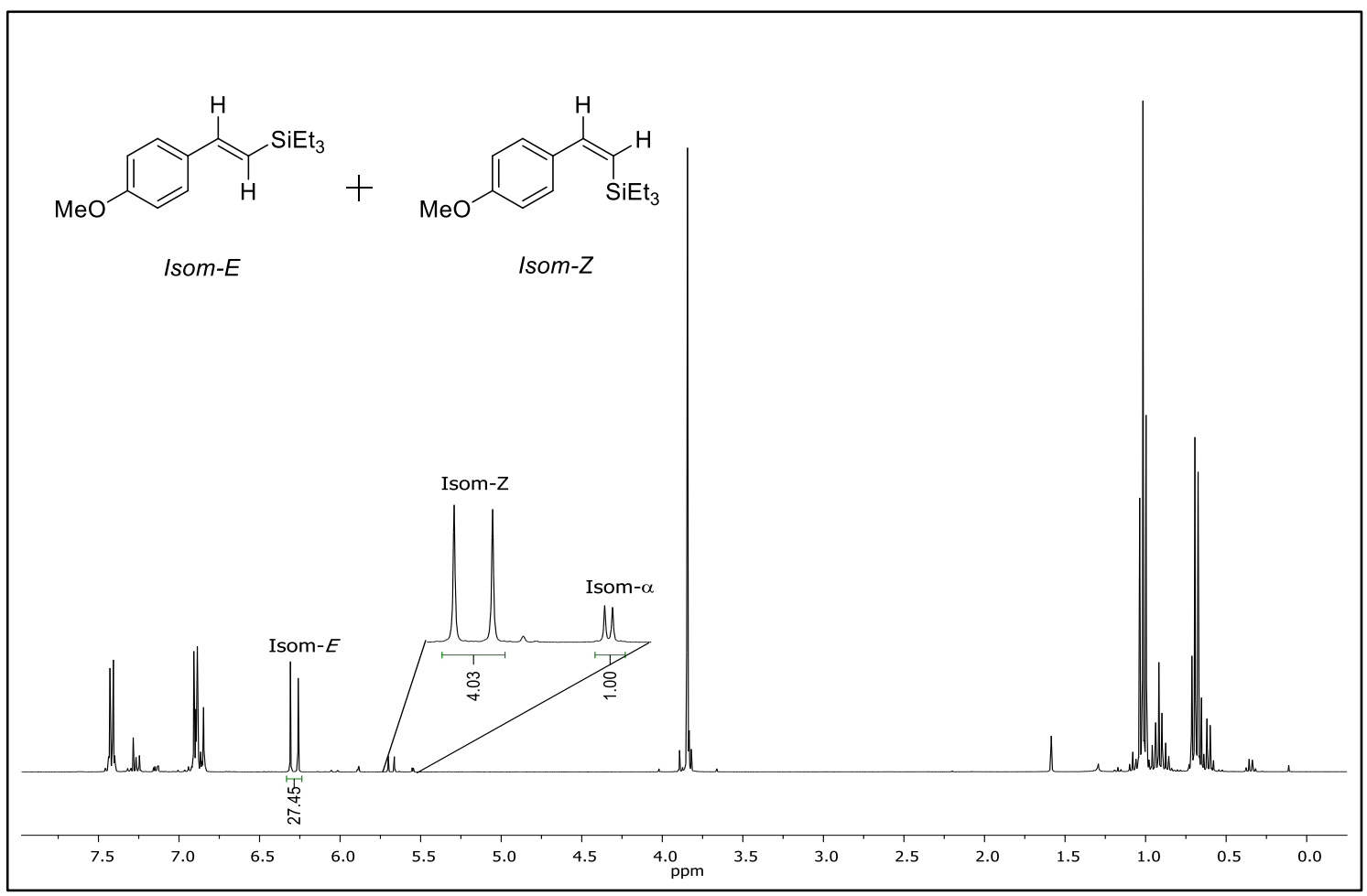

Figure S10. ${ }^{1} \mathrm{H}-\mathrm{NMR}$ spectrum $\left(400 \mathrm{MHz}, \mathrm{CDCl}_{3}\right.$ ) of the hydrosylation of 1-ethynyl-4methoxybenzene with triethylsilane using complex $\mathbf{2}$ as catalyst. 


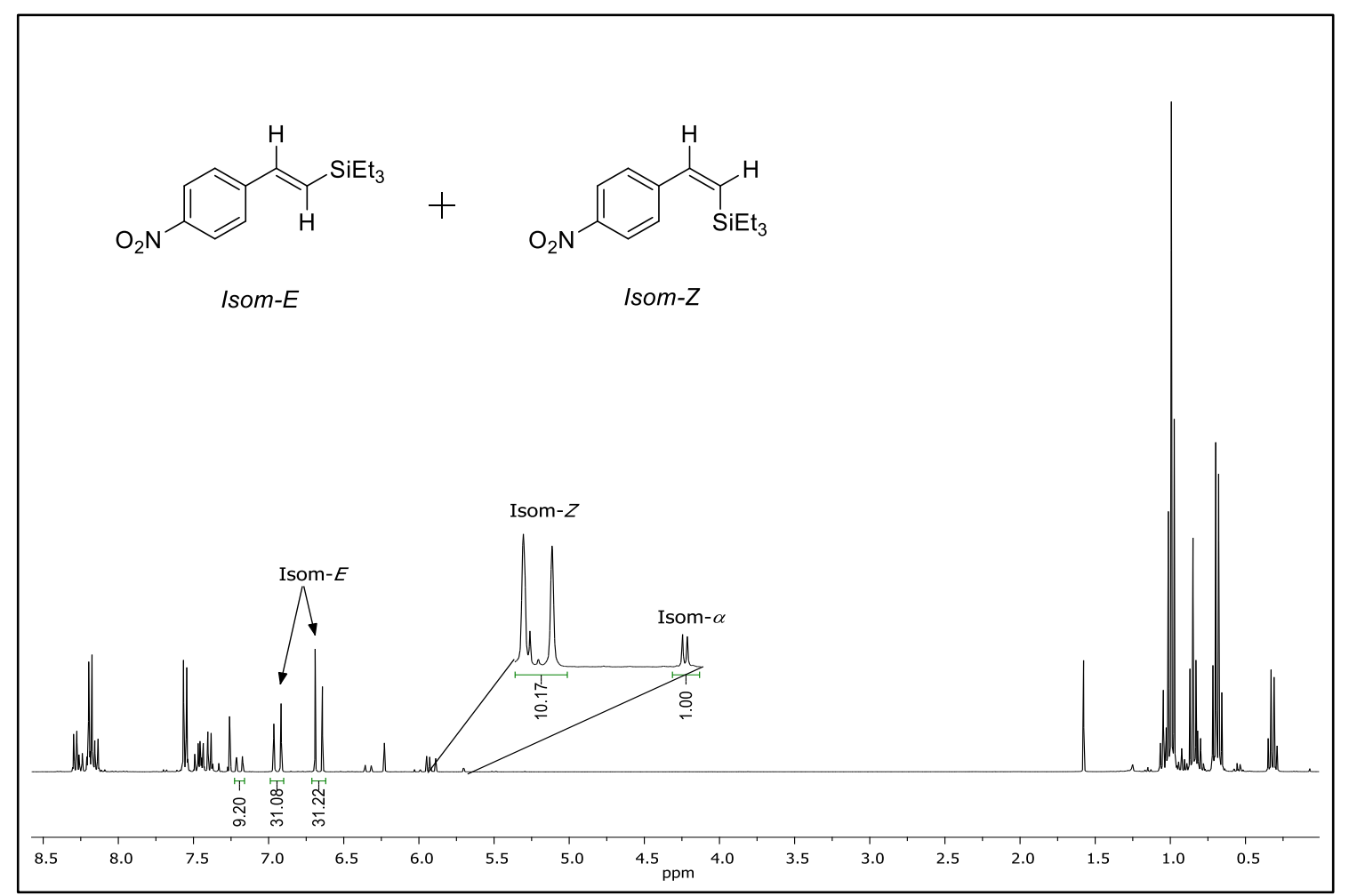

Figure S11. ${ }^{1} \mathrm{H}-\mathrm{NMR}$ spectrum $\left(400 \mathrm{MHz}, \mathrm{CDCl}_{3}\right)$ of the hydrosylation of 1-ethynyl-4nitrobenzene with triethylsilane using complex $\mathbf{2}$ as catalyst.

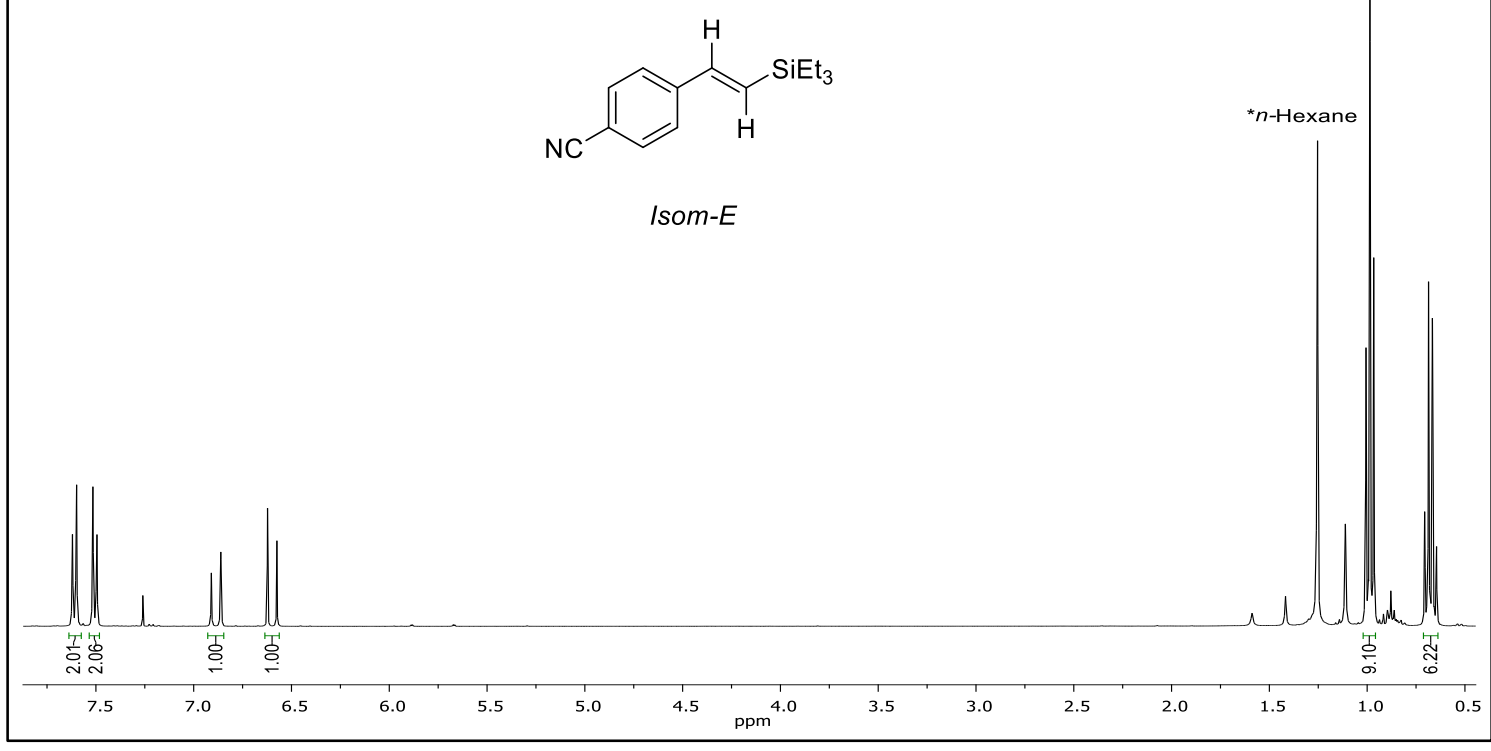

Figure S12. ${ }^{1} \mathrm{H}-\mathrm{NMR}$ spectrum $\left(400 \mathrm{MHz}, \mathrm{CDCl}_{3}\right.$ ) of the hydrosylation of 4-ethynylbenzonitrile with triethylsilane using complex $\mathbf{2}$ as catalyst. 


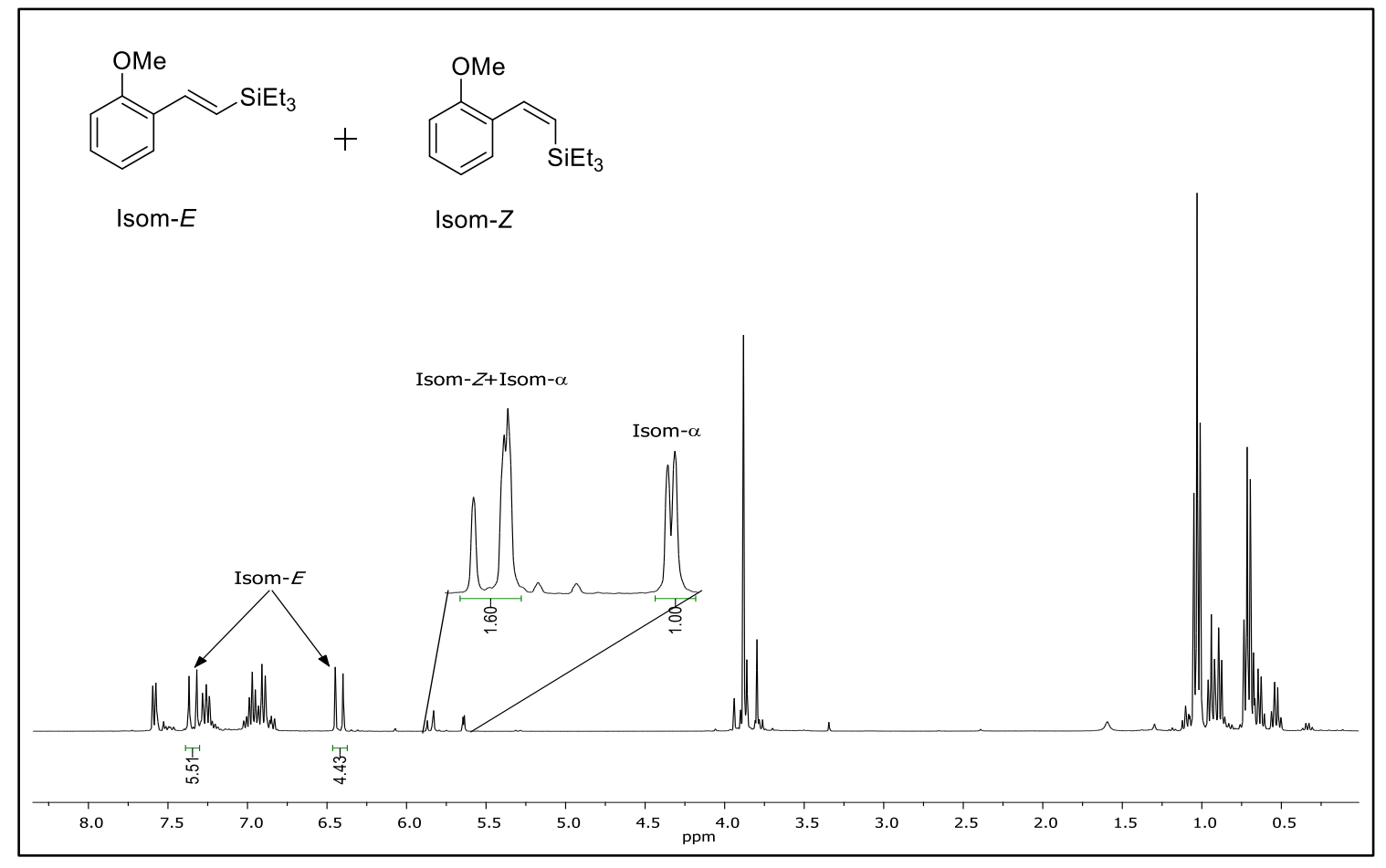

Figure S13. ${ }^{1} \mathrm{H}-\mathrm{NMR}$ spectrum $\left(400 \mathrm{MHz}, \mathrm{CDCl}_{3}\right)$ of the hydrosylation of 1-ethynyl-2methoxybenzene with triethylsilane using complex $\mathbf{2}$ as catalyst.

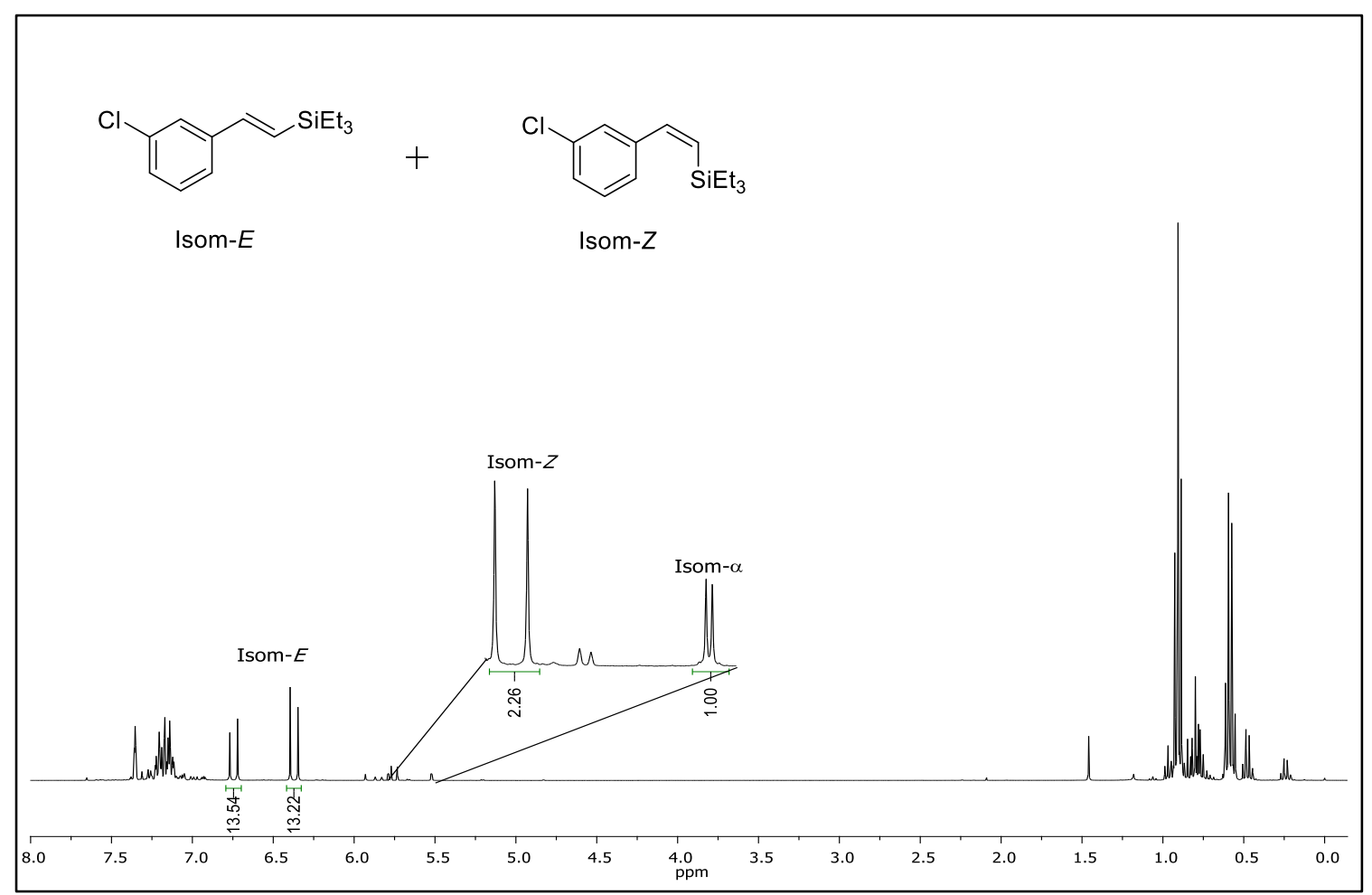

Figure S14. ${ }^{1} \mathrm{H}-\mathrm{NMR}$ spectrum $\left(400 \mathrm{MHz}, \mathrm{CDCl}_{3}\right)$ of the hydrosylation of 1-chloro-3ethynylbenzene with triethylsilane using complex $\mathbf{2}$ as catalyst. 


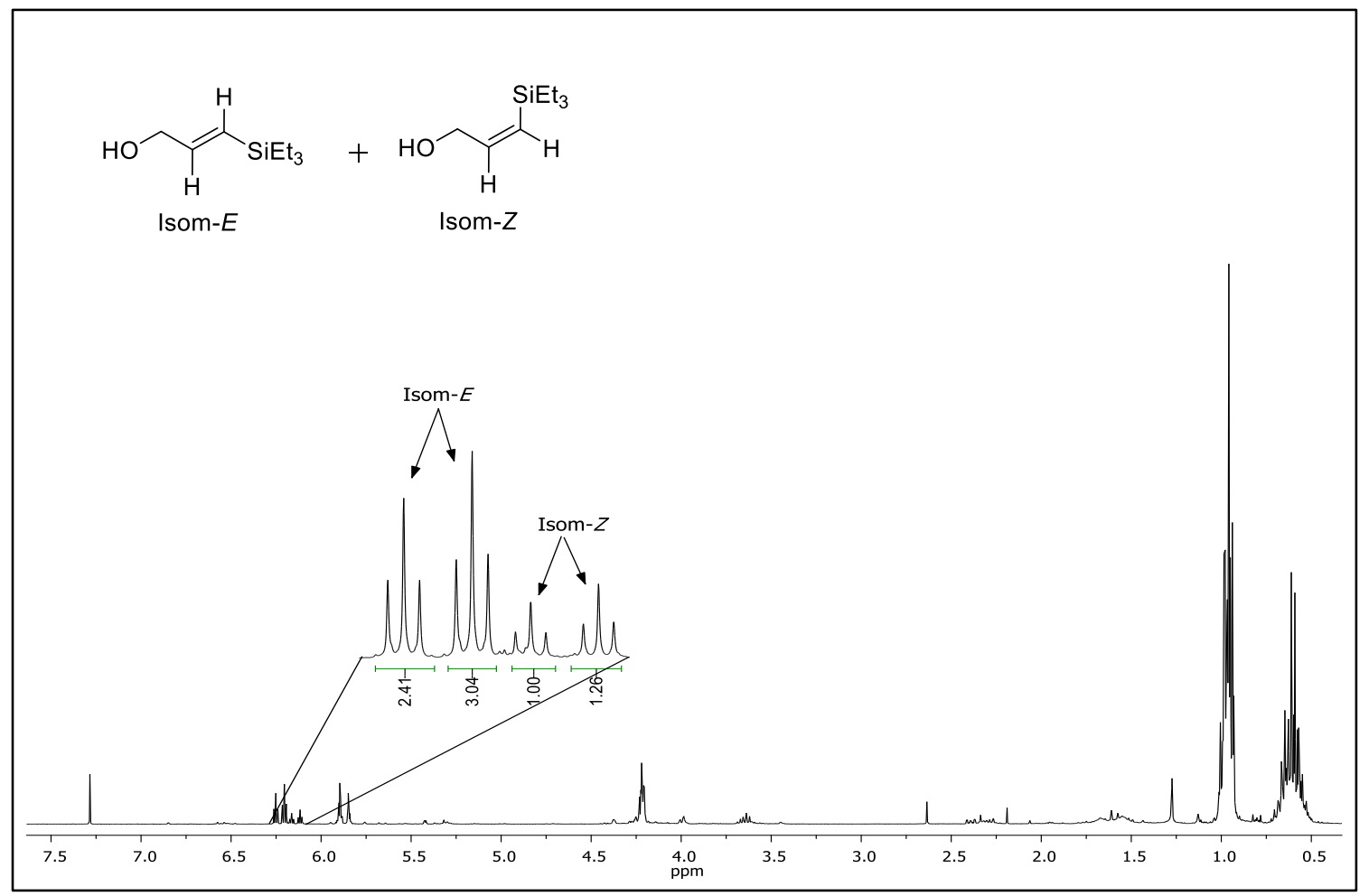

Figure S15. ${ }^{1} \mathrm{H}-\mathrm{NMR}$ spectrum $\left(400 \mathrm{MHz}, \mathrm{CDCl}_{3}\right)$ of the hydrosylation of propargyl alcohol with triethylsilane using complex 2 as catalyst.

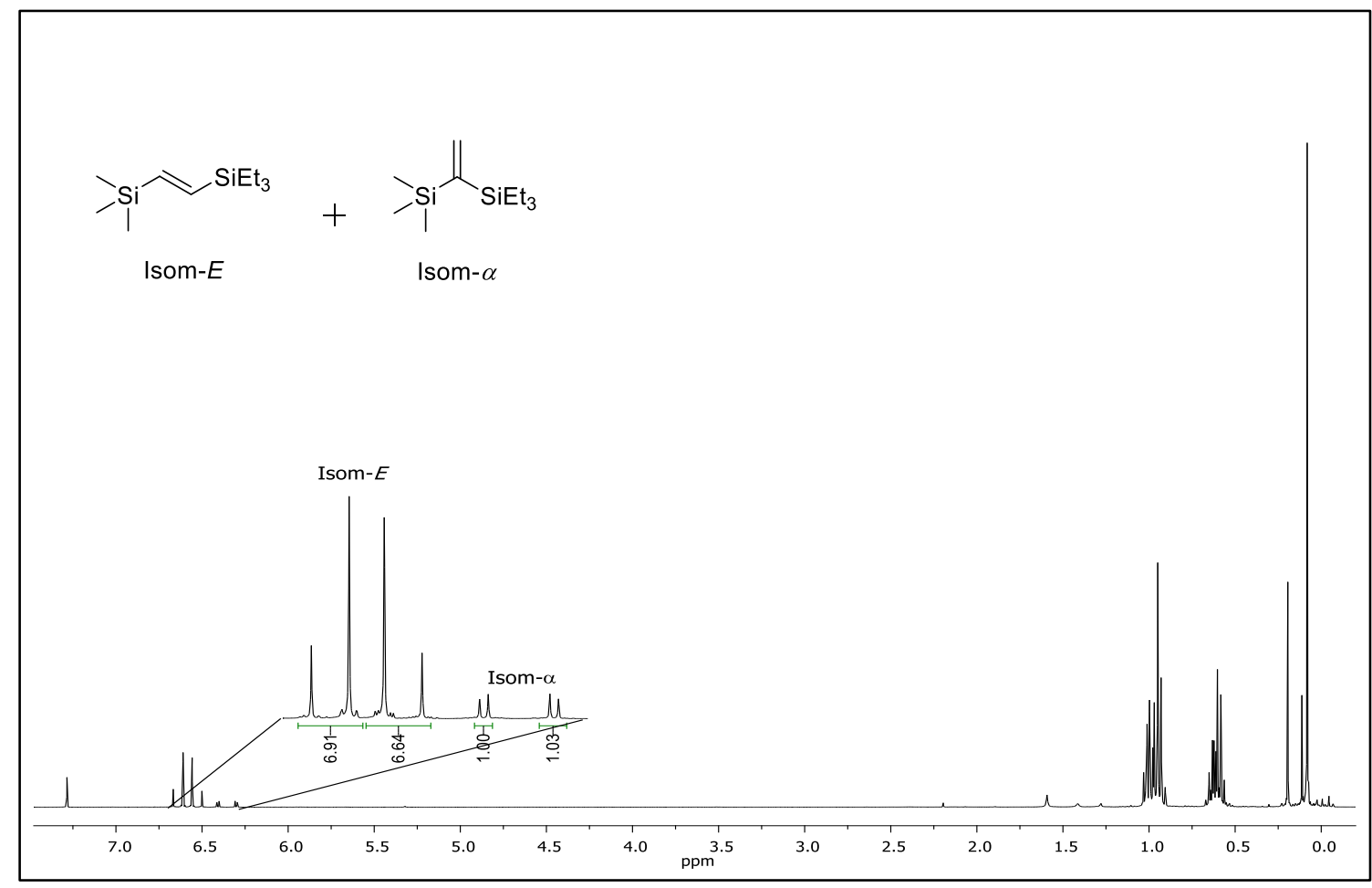

Figure S16. ${ }^{1} \mathrm{H}-\mathrm{NMR}$ spectrum $\left(400 \mathrm{MHz}, \mathrm{CDCl}_{3}\right)$ of the hydrosylation of ethynyltrimethylsilane with triethylsilane using complex $\mathbf{2}$ as catalyst. 


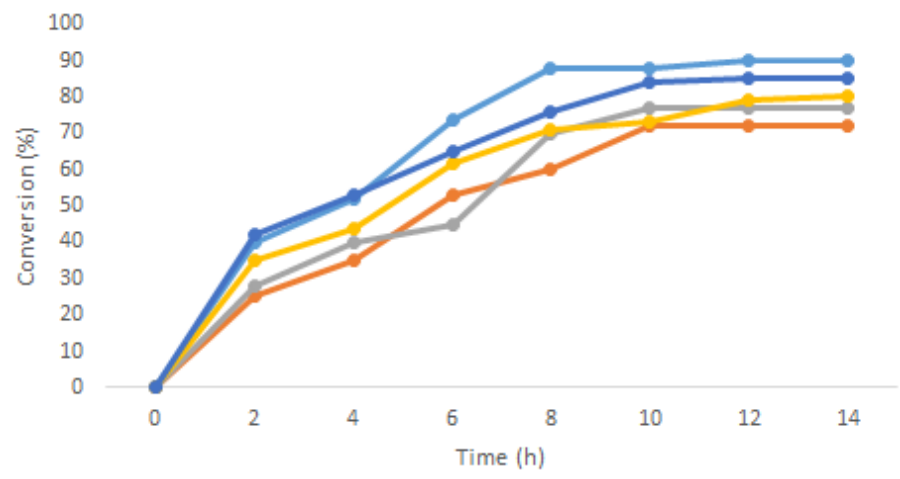

$\longrightarrow[2] \rightarrow[2] / H g(0 h) \multimap[2] / H g(2 h) \multimap[2] / H g(4 h) \multimap[2] / H g(6 h)$

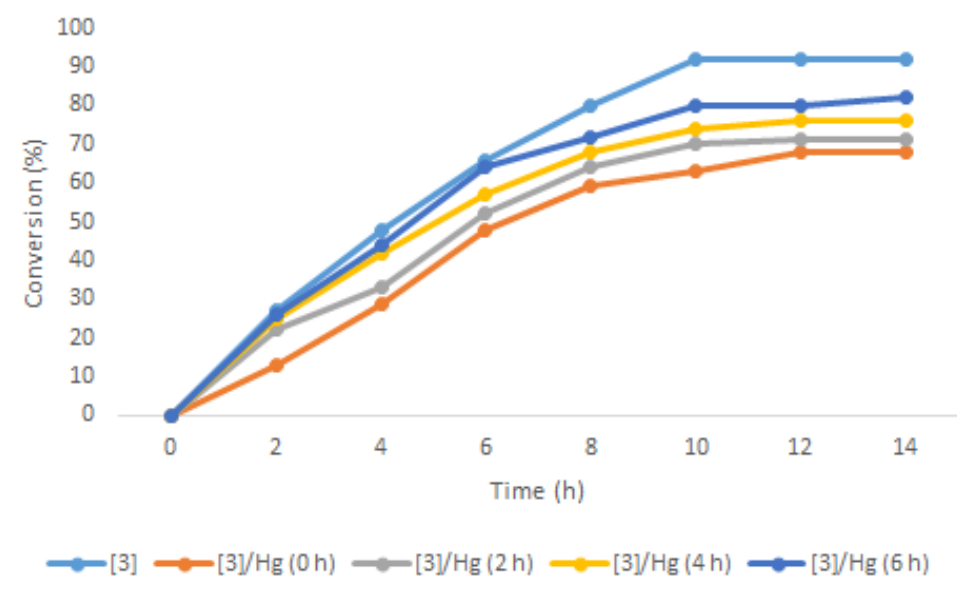

Figure S17. Mercury poisoning tests at different reaction times for the preparation of benzophenone catalyzed by complexes $\mathbf{2}$ (top) and $\mathbf{3}$ (bottom).

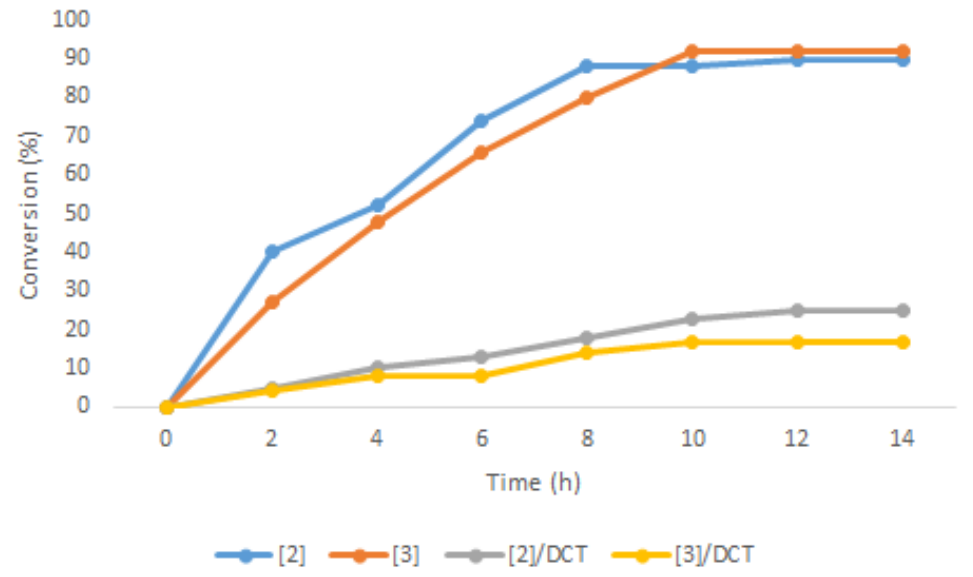

Figure S18. DCT poisoning tests $(t=0 \mathrm{~h})$ for the preparation of benzophenone catalyzed by $\mathbf{2}$ and $\mathbf{3}$. 


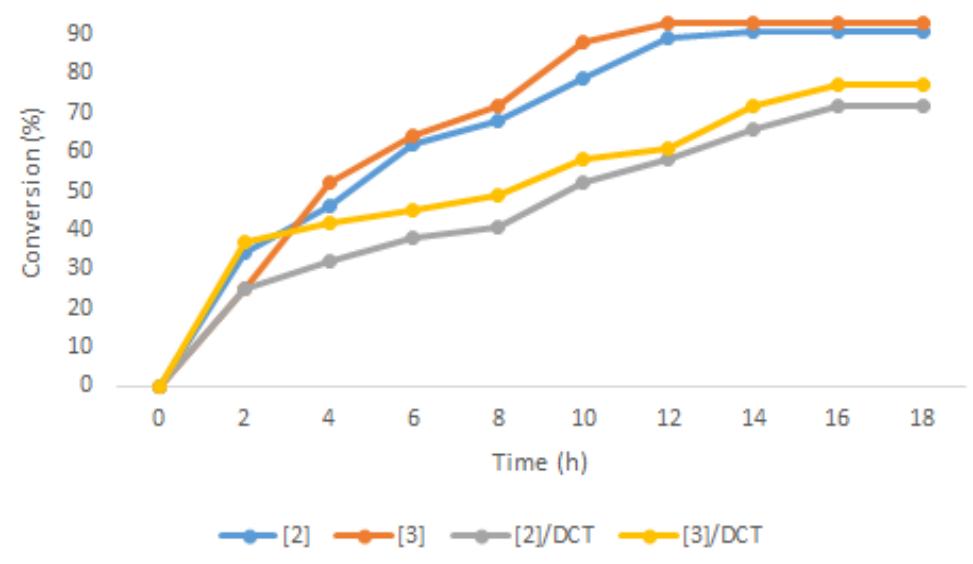

Figure S19. DCT poisoning tests $(\mathrm{t}=0 \mathrm{~h})$ for the preparation of benzylamide catalyzed by 2 and $\mathbf{3}$. 